\title{
Tricks, lies and mistakes: identifying Theory of Mind concepts within storybooks shared with deaf children
}

DOI:

10.1080/14643154.2017.1357779

\section{Document Version}

Accepted author manuscript

Link to publication record in Manchester Research Explorer

\section{Citation for published version (APA):}

Chilton, H. (2017). Tricks, lies and mistakes: identifying Theory of Mind concepts within storybooks shared with deaf children. Deafness and Education International. https://doi.org/10.1080/14643154.2017.1357779

\section{Published in:}

Deafness and Education International

\section{Citing this paper}

Please note that where the full-text provided on Manchester Research Explorer is the Author Accepted Manuscript or Proof version this may differ from the final Published version. If citing, it is advised that you check and use the publisher's definitive version.

\section{General rights}

Copyright and moral rights for the publications made accessible in the Research Explorer are retained by the authors and/or other copyright owners and it is a condition of accessing publications that users recognise and abide by the legal requirements associated with these rights.

\section{Takedown policy}

If you believe that this document breaches copyright please refer to the University of Manchester's Takedown Procedures [http://man.ac.uk/04Y6Bo] or contact uml.scholarlycommunications@manchester.ac.uk providing relevant details, so we can investigate your claim.

\section{OPEN ACCESS}




\section{Deafness \& Education International \\ Tricks, lies and mistakes: identifying Theory of Mind concepts within storybooks shared with deaf children \\ --Manuscript Draft--}

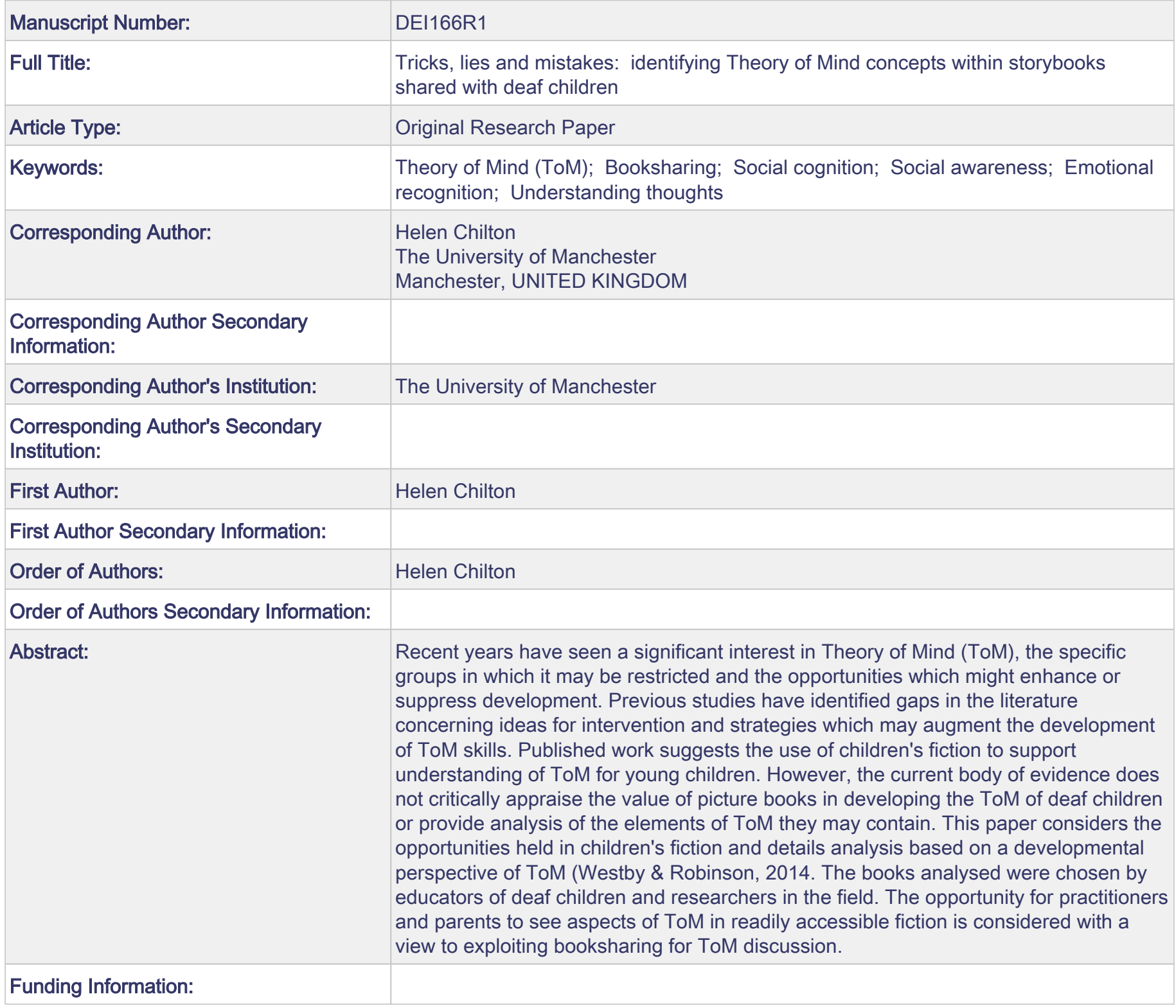


Tricks, lies and mistakes: identifying Theory of Mind concepts within storybooks shared with deaf children

Corresponding author:

Helen Chilton (Helen.chilton@manchester.ac.uk)

Communication and Deafness

Ellen Wilkinson Building

The University of Manchester

M13 9PL

Helen.chilton@manchester.ac.uk

$1^{\text {st }}$ Author: Helen Chilton 


\section{Tricks, lies and mistakes: identifying Theory of Mind concepts within storybooks shared with deaf children}

\section{Abstract}

Recent years have seen a significant interest in Theory of Mind (ToM), the specific groups in which it may be restricted and the opportunities which might enhance or suppress development. Previous studies have identified gaps in the literature concerning ideas for intervention and strategies which may augment the development of ToM skills. Published work suggests the use of children's fiction to support understanding of ToM for young children. However, the current body of evidence does not critically appraise the value of picture books in developing the ToM of deaf children or provide analysis of the elements of ToM they may contain. This paper considers the opportunities held in children's fiction and details analysis based on a developmental perspective of ToM (Westby \& Robinson, 2014). The books analysed were chosen by educators of deaf children and researchers in the field. The opportunity for practitioners and parents to see aspects of ToM in readily accessible fiction is considered with a view to exploiting booksharing for ToM discussion.

\section{Introduction}

Human beings are complex. Thoughts and emotions are complicated, abstract and invisible when isolated from the facial expressions, behaviours and words which support their recognition. As inhabitants of the social world we not only have the challenge of working with the set of thoughts and emotions that we hold but also in understanding the thoughts and emotions of others. When we communicate with others, people who are adept at navigating social situations are easy to recognise as are those who find navigating the social world more perplexing. However, whilst these skills are pivotal to our interactions, most people use them implicitly and without conscious thought. 
In academic literature, understanding the thoughts and emotions of ourselves and others is labelled Theory of Mind (ToM), a phrase coined by Premack and Woodruff (1978) and often described as 'mind-reading' or 'perspective taking'. The importance of the topic cannot be overlooked considering that refining and developing ToM skills can support the ability to empathise with others (Peterson, 2015), the making of reciprocated friends and prevention of friendlessness (Fink, Begeer, Peterson, Slaughter \& de Rosnay,2015; Peterson \& Siegal, 2002) and even peer-popularity (Peterson, O’Reilly \& Wellman, 2016). ToM is considered to be vulnerable within certain populations including those with Autistic Spectrum Disorder (ASD) (Baron-Cohen, Leslie \& Frith, 1985), deafness (Peterson \& Siegal 1998, O'Reilly et al. 2014) and other aetiologies (Byom \& Turkstra, 2012). Unlike the connection between ASD and ToM, the connection between deafness and ToM is indirect and hinged on the impact of the environment. The importance of shared common language in the home (Peterson \& Siegal 1995; Courtin 2000; Woolfe, Want \& Siegal, 2002; Schick, de Villiers, de Villiers \& Hoffmeister, 2007), exposure to conversations about mental states (Moeller \& Schick 2006), as well as environments and people who facilitate 'closeness' of communicative experiences (Woolfe \& Smith, 2001; Woolfe et al. 2002; Woolfe , Want \& Siegal, 2003) have been seen to be key to deaf children's ToM development. Whilst clear links between language and ToM development have been demonstrated, emerging evidence suggests a complex and interwoven relationship with deaf children's ToM ability predicting peer social skills over and above other factors such as age, gender, language ability and the impact of being a native or late-signer (Peterson, Slaughter, Moore \& Wellman, 2016). 
The developmental process of ToM in children is now well understood with clear frameworks describing the potential subskills involved and typical ages of development (Wellman \& Liu 2004; Westby \& Robinson 2014; Peterson, Wellman \& Slaughter, 2012). The idea that ToM is a unitary construct (i.e. the dimensions and aspects of ToM being one and the same) that emerges between the ages of four and five years has given way to the understanding of ToM as a multidimensional construct (Westby \& Robinson, 2014). This multidimensional construct involving the cognitive (thoughts) and affective (feelings) domains, pertains to self (intrapersonal) and others (interpersonal) (Westby \& Robinson, 2014). It is now acknowledged that ToM does not suddenly emerge but involves precursors which can be seen in infancy (Baillargeon, Scott \& He, 2010; Surian, Caldi \& Sperber, 2007). A review from Dvash and Shamay -Tsoory (2014) supports the multidimensional construct of ToM by identifying the neurophysiological / neuroanatomical functioning of the brain when exposed to different elements of ToM and empathy. This suggests a need for those who teach deaf children to have a working knowledge of its multidimensionality in the best interests of enabling opportunities for deaf children. It is hoped that the framework discussed later within this article will support the opportunities for applied teacher knowledge.

Literature in the field has called for practical and meaningful interpretations of research evidence which relate to classroom practice with deaf children (Chilton \& Beazley, 2014; Beazley \& Chilton, 2015; Chilton \& Beazley, under review; Swanwick \& Marschark, 2010). Outside of Deaf Education, a body of evidence has considered the connections between reading fiction and ToM. Studies note that adults who frequently read fiction function at an advanced level on measures of empathy and social cognition (Mar, Oatley, 
Hirsh, dela Paz \& Peterson, 2006; Mar, Oatley \& Peterson, 2009, Black \& Barnes 2015).

There are several contrasting ideas with respect to this. The first is that reading fiction has the potential to enhance ToM not due to the process of reading per se but due to the metalinguistic material embedded within the books. This is based on the premise that fiction contains characters, language or plots which are conducive to enabling readers to utilise their ToM skills. Within an adult population, Kidd and Castano (2013) evidence the effect of reading 'literary fiction' (described as writerly and polyphonic) on the development of ToM skills. Those who read literary fiction (in comparison to those who read non-fiction or popular fiction and non-readers) showed improved performance on ToM tasks. The work of Kidd and Castano (2013) and Zunshine (2011) suggests that reading fiction supports ToM development although there is a question of 'style' and it is unclear as to how long-lasting the effects may be (Kidd \& Castano, 2013). Considering empathy as one specific component of ToM enables us to see links between the development of empathy and reading fiction. Bal and Veltkamp (2013) and Stansfield and Bunce (2014) suggest that reading fiction enables readers to become more empathic than those who read non-fiction, but only when they are emotionally transported into the story. This is an important consideration for professionals in Deaf Education as a wealth of literature has evidenced the vulnerability of some deaf children to the development of empathy (Netten, Rieffe, Theunissen, Soede \& Dirks, 2015).

The second idea related to the meta-linguistic features of fiction is the inclusion of mental states within the book. These mental states may present as terms in the printed narrative (e.g. know, believe, guess, wonder) or in the 'talk around the book' in dialogic reading. Dyer, Shatz and Wellman (2000) found that children's books increase their 
reference to mental states according to age with books aimed at 5-6 year olds including a higher frequency of and wider variety of mental state references compared with those aimed at 3-4 year olds. Based on the inclusion of mental state terms, the findings indicate the potential of storybook reading for ToM development. Adrian, Clemente, and Villanueva (2007) evidenced that maternal use of cognitive verbs in storybook reading correlated to their children's later performance on ToM tasks.

Westby and Robinson (2014) and Nikolajeva (2013) suggest a range of books and consider the role of booksharing to enhance ToM development. With a specific focus to enhancing ToM skills in deaf children, Stanzione and Schick (2014) suggest that books such as 'Little Red Riding Hood' have potential to enhance children's exposure to dual mental representations although the specific ToM components in such books were not analysed. Concluding a study which specifically considered the need to enhance ToM skills in deaf children, Jones, Gutierrez and Ludlow (2015) discussed the need for research into the value of picture books as a mode of intervention with deaf children.

Considering the links between ToM and fiction reading from a different angle, there is evidence to suggest that refined abilities in ToM help the reader to understand the deeper meaning and inference of the book. Exemplifying this, Holmer, Hiemann and Rudner (2016) found a positive association between reading comprehension abilities and ToM in deaf children. In this study, Swedish Sign Language comprehension did not correlate to a more advanced ToM contrasting with earlier research (Courtin \& Melot, 2005) which showed that access to native sign supports ToM development when children are tested on false belief tasks. Similarly, Pelletier and Beatty (2015) found that second order ToM (for example, the ability to appreciate what a person is thinking/feeling about what another person is thinking 
/ feeling) predicted a hearing child's ability to understand Aesop's Fables (folktales characterised by themes of morality and deception). It emphasised the importance of mental state awareness in enabling children to judge character, intentionality and deeper messages within the story.

The evidence suggests a close relationship between reading fiction and ToM. Concepts of ToM are suggested to be deeply embedded in the context of books with potential to be utilised to support children's ongoing development but ToM is also suggested to be needed to truly understand the story. Whereas the adult UK population demonstrates great diversity in prevalence of reading (Booktrust 2013), we might assume that children have more regularity in exposure to fiction reading as this forms part of both the primary and secondary curriculum. In situations where ToM is seen to be vulnerable (e.g. for deaf children) the presence of ToM concepts in shared books may support development although it is recognised potential gains may be influenced by the type of books shared and the approach taken by the sharer. This paper considers a framework for identifying elements of ToM within children's picture books in order to support their progression of ToM skills. The paper considers the following:

1. Can the ToM framework in Westby \& Robinson (2014) be used to identify ToM within children's fiction?

1. What elements of ToM can be found in children's fiction storybooks shared with deaf children?

\section{Methodology}

Two previous reports (Beazley \& Chilton 2015; Chilton \& Beazley 2016, under review) discuss a project which considers the role of educators of deaf children, their understanding 
of ToM development and the strategies used when undertaking shared reading. Five Teachers of the Deaf (ToDs) within that study were asked to select books to read with deaf children in a booksharing activity. ToDs were asked to select books which focussed on "thoughts and beliefs", excluding books from book schemes designed to support emerging reading skills. Teachers were provided with examples of books to support thinking but selected their own choices (which could be one of the examples or a different book). This was reported in Beazley and Chilton (2015). The ToDs shared books with children they regularly work with aged between 4 and 8 years old, a time where children are typically displaying an increasing understanding of ToM (Westby \& Robinson, 2014). All the children and ToDs used English as their first language and the teachers worked in a range of settings including peripatetic services, resource bases in mainstream schools and in a school for the deaf. This paper considers the range of ToM concepts evident in the books used within the previously reported studies (Beazley \& Chilton 2015; Chilton \& Beazley 2016, under review).

\section{Analysis}

Five books are the focus of discussion for this paper. The books were read several times by the researcher to gain a grasp of the theme and subject matter of the book. Each book was then analysed for the following: linguistic features, number of pages, illustrative content, mean words per page, mental and emotional state terms and characters. This enabled the researcher to have an overview of the book before considering potential ToM concepts.

The basis for analysis of the ToM concepts in the books was derived from Westby and Robinson (2014) who suggest a framework for understanding subskills of ToM within the cognitive and affective domains and separate these into a developmental framework of ToM e.g. pre ToM skills, first order, second order and higher order skills. An adapted (with 
permission) overview from Westby and Robinson (2014) is shown here. The author

encourages readers to consult the original work for a comprehensive understanding.

Table 1: Development of Theory of Mind (Westby \& Robinson, 2014)

\begin{tabular}{|c|c|}
\hline $\begin{array}{l}\text { Four/five years } \\
\text { First order skills } \\
\text { Understanding } \\
\text { thoughts and } \\
\text { emotions }\end{array}$ & $\begin{array}{l}\text { - Attribute thoughts (cognitive) and feelings (affective) to } \\
\text { others } \\
\text { - } \quad \text { Pass false belief tasks } \\
\text { - Understand not only what people see but how it appears to } \\
\text { them } \\
\text { - Understand that we know information because we have seen } \\
\text { it or heard it } \\
\text { - Understand that beliefs cause people to act in certain ways } \\
\text { - Understand that thoughts and emotions are caused by what } \\
\text { - } \text { can deople think is the case even if this conflicts with reality } \\
\text { happy, sad, mad, scared, surprised and then more complex } \\
\text { emotions such as disgust and worry may emerge. }\end{array}$ \\
\hline $\begin{array}{l}\text { Six to eight years } \\
\text { Second order skills } \\
\text { Expanding } \\
\text { understanding of } \\
\text { range of thoughts and } \\
\text { emotions }\end{array}$ & $\begin{array}{l}\text { - Thinking about what one person is thinking/feeling about } \\
\text { what another is thinking/ feeling (e.g. A believes that B } \\
\text { believes; A knows that B feels) } \\
\text { - Understand that one can have first one emotion and then a } \\
\text { second emotion to the same situation } \\
\text { - Can judge situation and understand that people remember, } \\
\text { forget, guess } \\
\text { - Can describe situations where social emotions (requiring } \\
\text { understanding of mental states of others) such as jealousy, } \\
\text { pride, shame, guilt may emerge }\end{array}$ \\
\hline$\frac{\text { Eight years plus }}{\text { Higher order skills }}$ & $\begin{array}{l}\text { - Multiple embeddings e.g. "She thinks that her mother knows } \\
\text { - } \text { that her brother hopes his girlfriend will want the gift" } \\
\text { - figurative language, idioms } \\
\text { - Understand that people may use strategies to hide deceit and } \\
\text { to detect deceit } \\
\text { - Presentational lies (making oneself look good in the eyes of } \\
\text { others) } \\
\text { - Understand that one can have concurrent emotions of } \\
\text { opposite types }\end{array}$ \\
\hline
\end{tabular}

Precis from Westby and Robinson 2014 (with permission)

Domains of Theory of Mind (Westby \& Robinson, 2014)

\begin{tabular}{|l|l|}
\hline Cognitive ToM: & attribute mental states (e.g. know, believe, wonder, guess) \\
\hline Affective ToM: & recognise emotions \\
\hline
\end{tabular}




\begin{tabular}{|l|l|}
\hline Interpersonal ToM: & cognitive and affective ToM for others \\
\hline Intrapersonal ToM: & cognitive and affective ToM for self \\
\hline
\end{tabular}

Westby and Robinson (2014) (with permission)

The developmental trajectory outlined in Westby and Robinson (2014) was used as a theory-driven code (Boyatzis, 1998), enabling the researcher to consider elements of the books which relate to the order of ToM skills (i.e. first order through to higher order). The books were coded by the author, noting each possible thread of ToM with the potential for exploitation by those who teach deaf children. It is acknowledged that other readers of the books may highlight different aspects than have been reported here (as we all infer meaning to the written word). However, the paper here presents a starting point from a researcher / practitioner who is familiar with developmental aspects of ToM and children's literature and has previously reported on aspects of ToM in 'Strange Stories' (Chilton \& Beazley, 2014).

Results

Overview of books

The included books are readily available in the UK and are used within primary settings in the United Kingdom. It is expected that readers of Deafness and Education International are familiar with some or all of the books. An overview of the style of each book can be seen in Appendix 1

-Appendix 1 -

\section{Analysis of ToM content}

All books within the study included a depth and variety of ToM concepts. The books incorporated these features in a multitude of ways. Two of the books demonstrated the opportunity to discuss first and second order concepts. Three of the books demonstrated the opportunity to discuss first, second order and higher order concepts. 
-Appendix 2-

One of the books within the study; The Gruffalo by Donaldson (1999), demonstrates a plethora of higher order elements of ToM, including the opportunity to discuss multiple embeddings, the understanding of strategies to hide and detect deceit and presentational lies. Whilst Eat Your Peas (Gray \& Sherratt, 2007) was linguistically simple and visually clear, it lent itself to discussing lies and persuasion and may be used to invoke discussion including higher order elements. Within Arthur's Tractor (Goodhart, 2003) there was the opportunity to exploit the illustrative content which demonstrated that Arthur did not know about the story which was unfolding behind him. Handa's Surprise (Browne, 2006) and Mrs Rainbow (Griffiths, 2006) included opportunities to promote discussion of first and second order ToM. Whilst Handa's Surprise is regularly used in UK primary setting for vocabulary work due to the range of animals and tropical fruits, the opportunities for ToM-based work appear integral to the book with Handa continuing the journey with the false belief that she was still carrying the range of fruits.

Whilst research has shown the potential for parental use of mental state terms in augmenting ToM understanding (Moeller \& Schick, 2006) the books in this study did not rely on this to overtly display ToM concepts. For example, in The Gruffalo, only one emotional state term (afraid) and one mental state term is used (know). However, this book includes a range of ToM concepts from first order up to higher order levels and presented as the most cognitively complex book when considering such concepts. Mrs Rainbow included the most words per page, more mental and emotional state terms and comparatively more complex words that other books in the study. However, these features of the book did not correlate to a more extensive range of ToM concepts within the book. Books with fewer words per page (e.g. Handa's Surprise) still gave the opportunity for discussion of ToM concepts with a range of second order elements being integral to the book.

\section{Discussion}


In support of earlier theories, it appears that picture-book fiction contains content that could be used to stimulate the development of ToM (Westby \& Robinson 2014, Stanzione \& Schick 2014). All books contained plots conducive to discussing ToM with deaf children and these ranged across first order, second order and higher order concepts. Whilst previous studies identified the potential of booksharing, this study offers a meta-analysis of five examples used with deaf children by applying knowledge of ToM concepts (Westby \& Robinson, 2014).

A dichotomy between research and practice in ToM and deaf children has been suggested in the literature (Swanwick \& Marschark 2010, Beazley \& Chilton 2015) and emerging evidence demonstrates the importance of knowledge of developmental ToM as a subject specialism for practitioners who work with deaf children (Chilton \& Beazley, under review). This paper acknowledges that cognitively complex ideas are stored in picture books designed for young children. In establishing a starting point for identifying ToM themes in picture-book fiction it is hoped that practictioners will continue to recognise ToM themes in other books and work with others in doing so (e.g. parents, mainstream teachers). The most cognitively advanced book in terms of ToM concepts (The Gruffalo) displayed several themes which would be considered within the Westby \& Robinson (2014) framework as developing as higher order skills, aged 8 and beyond. However, this book is regularly used with children in early-years settings and, by the age of 8 , children and teachers have generally progressed to more linguistically challenging reading materials. For some older deaf children there may be a place for the use of texts with accessible vocabulary if the intended outcome is to improve ToM skills and the content within the book can be guaranteed to be richly exploited.

Whilst there is a wealth of knowledge that maternal input of mental state terms is closely correlated to later success with ToM based tasks (de Rosnay \& Hughes, 2006; Laranjo, Bernier, Meins \& Carlson, 2010, Moeller \& Schick, 2006), there was no correlation between high levels of mental state and emotional state terms and opportunity for discussion of ToM concepts within the 
books in this study. This sits in agreement with research from Adrian et al. (2007) where mothers' use of cognitive verbs when sharing wordless picture books had a positive correlation to children's later performance on ToM tasks. The study suggests that the use of wordless picture books meant that mothers did not rely on the inclusion of cognitive verbs within the written text of the story. Similarly, Peskin \& Astington (2004) compared a book (Rosie's Walk) which had been adapted to include explicit metacognitive verbs with a version that did not include such metacognitive verbs. The control group (without explicit metacognitive verbs) exceeded the group with metacognitive verbs on later false-belief tasks. It was suggested that this may be because the control group had to actively construct their own interpretation of the stories. As Narvaez (2002) notes the integral role of the adult in identifying inference and supporting the child's ability to construct meaning. This illustrates the critical nature of teacher subject-knowledge of ToM (Chilton \& Beazley, under review).

The variety of approaches used in booksharing with deaf children is noted by Swanwick and Watson (2007) who found that families using spoken language focused on the features of the text and had less inclination to use the book to promote wider knowledge. History has warned of the damaging effect of simplifying conversations with deaf children (Wood et al., 1986). The need to ensure ease of communication must be balanced with the vital roles that those around the child have in supporting social cognition. Whilst 'strategies for intervention' may be discussed in the field here are a selection of books, readily available amongst many others, which already include a range of opportunities for parents and teachers alike to enhance children's ToM understanding.

Some of the books within the study are highly acclaimed in the UK (TES, 2015; The Guardian, 2014). It is unclear whether this is because complex elements of ToM form such an integral part of the plot (as in The Gruffalo). It is possible that a depth of ToM concepts supports a book's ability to be read and reread with discussion taking shape in different ways. The introduction to this paper discussed Kidd \& Castano's (2013) research which identifies 'literary fiction'. There is room for debate as to whether this extends to children's literature. Whilst this paper considers the 
opportunities in texts for primary aged deaf children there is clear opportunities in texts for older children. Considering books for older primary readers such as Esio Trot (Dahl, 1991) and books from the secondary curriculum such as Stone Cold (Swindells, 1995) (suggested by Angela Mather, ToD) may provide the opportunity to extend this work. Whilst ToM is not referred to explicitly within U.K. curriculum, it is a prerequisite to many elements therein such as to be able to infer when reading or to anticipate the answer sought by the examiner within assessments. Whilst practitioners and families find ways to work with deaf learners to enable access to reading materials from the secondary curriculum there may the underlying opportunity to use them to exploit ToM understanding.

Whilst books give a permanent and physical representation of ToM it is important to recognise the potential to work on social cognition through other mediums. Black and Barnes (2015) discuss the impact of TV drama viewing on the development of ToM. They found that people who viewed TV drama performed significantly better on the 'Reading the mind in the eyes' task than those who viewed a documentary. This suggests that it is not the medium (e.g. books, films) which may aid ToM development but the opportunity to see the embedded ToM themes. As we move towards a sophisticated and developmental understanding of ToM it is hoped that those around deaf children will find examples in the ordinary and everyday world. It is how those examples are exploited that is likely to make the difference.

\section{Conclusion}

All five books discussed within this paper showed evidence of the inclusion of ToM including first, second-order and higher-order concepts demonstrating the potential that 'off the shelf' fiction has in enhancing deaf children's ToM. The developmental framework by Westby and Robinson (2014) supported the identification of ToM concepts in books which had been shared with deaf children. Frameworks such as this may support ToDs as a form of aide memoir and the model of analysing children's fiction for ToM concepts could enable others to select books with ToM contents. The 
model presented here may also support practitioners to consider how they might exploit concepts within a book already in use in the classroom. Future directions may include consideration of books suitable for older children including books which form part of the secondary curriculum. Further practice-centred work with deaf children is required to understand the impact that this form of shared reading may have on the progression of deaf children's skills and endeavours in the social world. The consideration of how practitioners work with older deaf children and adolescents is sparse within the literature but measures which take into account the multidimensional and holistic nature of ToM are beginning to emerge (Hutchins, Allen \& Schefer, 2017) and may be used in conjunction with focussed booksharing to evidence progress that deaf children and young people are able to make with highly specialised support.

Parents and practitioners who work with deaf children in the UK are now challenged not only to focus on the development of spoken or signed language but to work within the subtlety of that developing language. With a noted lack of clarity as to how ToM should be assessed in deaf children (Beazley \& Chilton, 2015) there lies the risk that it can appear intangible and abstract in practice. However, as theory discusses the move from a unitary construct to a multidimensional construct, practice must move too. The move for practice is to understand and see ToM in its multidimensional form (affective / cognitive; pre-ToM to higher order, intra/interpersonal ToM skills) and in a multitude of settings and mediums. Whilst this paper enables readers to see a tangible representation of ToM concepts identified in books shared with deaf children there is still much to learn in practical application. 


\section{References}

Adrian J.E., Clemente, R.A. \& Villanueva, L. (2007). Mothers' Use of Cognitive State Verbs in Picture-book Reading and the Development of Children's Understanding of Mind: a Longitudinal Study. Child Development, 78(4):1052-67. doi:10.1111/j.1467-8624.2007.01052.x

Baillargeon, R., R. Scott, \& He Z. (2010). False-Belief Understanding in Infants. Trends in Cognitive Sciences, 14(3): 110-118. doi: 10.1016/j.tics.2009.12.006

Baron-Cohen, S., A. M. Leslie \& Frith U. 1985. Does the Autistic Child Have a 'Theory of Mind'? Cognition, 21: 37-46.

Bal, P.M. \& Veltkamp, M. (2013). How Does Fiction Reading Influence Empathy? An Experimental Investigation on the Role of Emotional Transportation. PLoS One,.8(1) e55341. doi: 10.1371/journal.pone.0055341.

Beazley, S. \& Chilton, H.(2015). The Voice of the Practitioner: Sharing Fiction Books to Support the Understanding of Theory of Mind in Deaf Children. Deafness \& Education International, 17(4):231 - 240. doi:10.1179/1557069X15Y.0000000010

Black, J. \& Barnes, J. (2015). The Effects of Reading Material on Social and Non-Social Cognition. Poetics, 52: 32-43. doi:10.1016/j.poetic.2015.07.001.

Booktrust (2013) Reading Habits Survey 2013. A national survey of reading habits and attitudes to books amongst adults in England http://www.djsresearch.co.uk

Boyatzis, R.E. (1998). Transforming Qualitative Information: Thematic Analysis and Code Development. Thousand Oaks, London,\& New Delhi: SAGE Publications.

Browne E. (2006) Handa's Surprise. Walker Books ISBN-10: 0744536340

Byom, L., \& Turkstra, L.(2012). Effects of Social Cognitive Demand on Theory of Mind in Conversations of Adults with Traumatic Brain Injury. International Journal of Language and Communication Disorders, 47(3): 310-21. doi:10.1111/j.1460-6984.2011.00102.x.

Chilton, H. \& Beazley S. (2014) Theory of Mind: Are There Wider Implications From Working With d/Deaf People? Disability and Society, 29(2): 184-197. doi:10.1080/09687599.2013.816623 
Chilton, H. \& Beazley S. (under review). Reading the Mind or Only the Story? Sharing fiction books to support Theory of Mind development in deaf children.

Courtin, C. (2000). The Impact of Sign Language on the Cognitive Development of Deaf Children: The case of theories of mind. Journal of Deaf Studies and Deaf Education, 5, 266-276. ISSN-1081-4159

Dahl , R. (1991). Esio Trot. Penguin Books Limited (UK), 1991

de Rosnay, M. \& Hughes, C. (2006). Conversation and Theory of Mind: do Children Talk Their way to Socio-cognitive Understanding? British Journal of Developmental Psychology, 24: 7-37. doi: $10.1348 / 026151005 \times 82901$

Donaldson, J. (1999). The Gruffalo. Macmillan Children's Books ISBN: 9780230747937

Dvash, J. \& Shamay-Tsoory, S. (2014). Theory of Mind and Empathy as Multidimensional Constructs: Neurological Foundations. Topics in Language Disorders, 34(4):282-295. doi: 10.1097/TLD.0000000000000040

Dyer J., Shatz M. \& Wellman H. (2000). Young Children's Storybooks as a Source of Mental State Information. Cognitive Development, 15(1):17-37. doi: 10.1016/S0885-2014(00)00017-4.

Fink, E., Begeer, S., Peterson, C.C., Slaughter, V. \& de Rosnay, M (2015). Friendlessness and Theory of Mind: A Prospective Longitudinal Study. British Journal of Developmental Psychology, 33(1):1-17. doi:10.1111/ bjdp.12060.

Goodhart , P. (2003). Arthur's Tractor. Bloomsbury Publishing PLC ISBN: 0747564787

Grey , K. \& Sherratt, N. (2007). Eat Your Peas . Random House Children's Publishers UK, ISBN10 1862302324

Griffiths, N. (2006). Mrs Rainbow. Red Robin Books ISBN: 9781905434930

Holmer E., Hiemann, M. \& Rudner M. (2016). Theory of Mind and Reading Comprehension in deaf and hard-of hearing signing children. Frontiers in Psychology, 7 (854)

doi:10.3389/fpsyg.2016.00854 
Jones A., Gutierrez R. \& Ludlow, A., (2015). Confronting the Language Barrier: Theory of Mind in Deaf Children. Journal of Communication Disorders, 56, 47-58. doi:

10.1016/j.jcomdis.2015.06.005

Kidd, D.C. \& Castano E. (2013). Reading Literary Fiction Improves Theory of Mind. Science, 342: 377-380. doi: 10.1126/science.1239918

Kovács, Á.M., E. Téglás, \& Endress, A.D. (2010). The Social Sense: Susceptibly to Sthers' Beliefs in Human Infants and Adults. Science, 330: 1830-1834. doi: 10.1126/science.1190792

Laranjo, J., Bernier, A., Meins, E. \& Carlson, S. M. (2010). Early Manifestations of Children's Theory of Mind: The Roles of Maternal Mind-Mindedness and Infant Security of Attachment. Infancy, 15: 300-323. doi: 10.1111/j.1532-7078.2009.00014.x

Mar, R. A., Oatley, K., Hirsh, J., dela Paz, J. \& Peterson, J. B. (2006). Bookworms Versus Nerds: Exposure to Fiction Versus Non-fiction, Divergent Associations With Social Ability, and the Simulation of Fictional Social Worlds. Journal of Research in Personality, 40(5): 694-712, doi: 10.1016/j.jrp.2005.08.002

Mar, R. A., Oatley, K. \& Peterson, J. B. (2009). Exploring the Link Between Reading Fiction and Empathy: Ruling out Individual Differences and Examining Outcomes. Communications 34(4): 407-428. doi:10.1515/COMM.2009.025

Moeller, M.P. \& Schick B.S. (2006). Relations Between Maternal Input and Theory of Mind Understanding in Deaf Children. Child Development, 77, 751-66. doi: 10.1111/j.14678624.2006.00901.x

Narvaez, D. (2002). Does Reading Moral Stories Build Character? Educational Psychology Review, 14, 155-171. doi:10.1023/A:1014674621501

Netten, A.P., Rieffe, C., Theunissen, S., Soede, W. \& Dirks E. (2015). Low Empathy in Deaf and Hard of Hearing (Pre)Adolescents Compared to Normal Hearing Controls. PLOS ONE, 10(40). doi: 10.1371/journal.pone.0124102

Nikolajeva, M. (2013). Picturebooks and Emotional Literacy. The Reading Teacher, 67(4): 249-254. doi:10.1002/trtr.1229 
O'Reilly, K., Peterson, C. C., \& Wellman, H. M. (2014). Sarcasm and Advanced Theory of Mind Understanding in Children and Adults with Prelingual Deafness. Developmental Psychology, 50(7), 1862-1877. doi: 10.1037/a0036654

Peskin J. \& Astington, J.W . (2004). The Effects of Adding Metacognitive Language to Story Texts. Cognitive Development, 19 : 253-273. doi: 10.1016/j.cogdev.2004.01.003

Peterson, C. C. \& Siegal M. (2002). Mindreading and Moral Awareness in Popular and Rejected Preschoolers. British Journal of Developmental Psychology, (20)205-224 doi:10.1348/026151002166415

Peterson, C. (2015). Empathy and Theory of Mind in Deaf and Hearing Children . Journal of Deaf Studies and Deaf Education. 21 (2): 141-147. doi:10.1093/deafed/env058 Peterson, C.C., O'Reilly, K. \& Wellman, H.M. (2016a). Deaf and Hearing Children's Development of Theory of Mind, Peer Popularity, and Leadership During Middle Childhood. Journal of Experimental Child Psychology 149:146-58. doi: 10.1016/j.jecp.2015.11.008

Peterson, C. Slaughter, V. Moore, C. \& Wellman, H.M. (2016b) Peer Social Skills and Theory of Mind in Children with Autism, Deafness, or Typical Development. Developmental Psychology. 52(1):46-57. doi: 10.1037/a0039833. Peterson, C. C., \& Siegal M. (1995). Deafness, Conversation and ToM. Journal of Child Psychology \& Psychiatry, 36, 459-474. doi:10.1111/j.14697610.1995.tb01303.x

Peterson, C. C., \& Siegal, M. (1998). Changing Focus on the Representational Mind: Deaf, Autistic and Normal Children's Concepts of False Photos, False Drawings and False Beliefs. British Journal of Developmental Psychology, 16, 301-20. doi:10.1111/j.2044-835X.1998.tb00754.x

Peterson, C. C., Wellman, H. M. \& Slaughter, V. (2012), The Mind Behind the Message: Advancing Theory-of-Mind Scales for Typically Developing Children, and Those With Deafness, Autism, or Asperger Syndrome. Child Development, 83:469-485. doi:10.1111/j.14678624.2011.01728.x

Premack, D. \& Woodruff, C. (1978). Does the Chimpanzee Have a Theory of Mind? Behaviour and Brain Sciences, 1 (4) 515-526. doi:10.1017/S0140525X00076512 
Russell, P. A., J. A. Hosie, C.D. Gray, C. Scott, N. Hunter \& Banks, J., (1998). The Development of ToM in Deaf Children. Journal of Child Psychology and Psychiatry, 39, 903-10. doi:10.1111/1469-7610.00390

Schick B., P. de Villiers, J. de Villiers \& Hoffmeister R.(2007). Language and Theory of mind: A Study of Deaf Children. Child Development. 78 (2), 376-96. doi:10.1111/j.1467-8624.2007.01004.x

Stansfield, J. \& Bunce, L.(2014). The Relationship Between Empathy and Reading Fiction: Separate Roles for Cognitive and Affective Components. Journal of European Psychology Students. 5(3) 9-18. doi:10.5334/jeps.ca

Stanzione, C. \& Schick B.(2014). Environmental Language Factors in Theory of Mind Development: Evidence from Children who are deaf/ hard of hearing or who have specific language impairment. Topics in Language Disorders. 34. 296 - 312 doi: 10.1097/TLD.0000000000000038

Surian, L.\& Caldi, S. \& Sperber, D. (2007). Attribution of Beliefs by 13-month-old Infants. Psychological Science, 18(7): 580-586.doi:10.1371/journal.pone.0072835

Swanwick, R. \& Watson, L. (2007). Parents Sharing Books With Young Deaf Children in Spoken English and in BSL: The Common and Diverse Features of Different Language Settings. Journal of Deaf Studies and Deaf Education. 12(3): 385-405. doi:10.1093/deafed/enm004

Swanwick, R. \& Marschark, M. (2010). Enhancing Education for Deaf Children: Research into Practice and Back Again. Deafness \& Education International, 12 (4) 217-235. doi: 10.1179/1557069X10Y.0000000002 Swindells R. (1995) Stone Cold. Puffin Teenage Fiction Symons, D. K., Fossum, K. \& Collins, T.B. K. (2006). A Longitudinal Study of Belief and Desire State Discourse During Mother-Child Play and Later False Belief Understanding. Social Development, 15:676-692. doi:10.1111/j.1467-9507.2006.00364.x

Times Educational Supplement (2015) 100 Fiction Books All Children Should Read Before Leaving Primary School. www.tes.com/news/school-news/breaking-news/100-fiction-books-allchildren-should-read-leaving-primary-school-\%E2\%80\%93

The Guardian (2014) Diverse Voices: the 50 Best Culturally Diverse Children's Books 
www.theguardian.com/childrens-books-site/2014/oct/13/50-best-culturally-diverse-childrensbooks

Wellman, H. M. \& Liu, D. (2004). Scaling of Theory-of-Mind Tasks. Child Development, 75:523-541. doi:10.1111/j.1467-8624.2004.00691.x

Westby C. \& Robinson L. (2014). A Developmental Perspective for Promoting Theory of Mind. Topics in Language Disorders, 34 (4) 362-382 doi:10.1097/TLD.0000000000000035

Wood, D., Wood, H., Griffiths, A. \& Howarth, I. (1986) Teaching and Talking With Deaf Children. John Wiley. ISBN 0471908274

Woolfe, T., \& Smith, P. K. (2001). The Self-Esteem and Cohesion to Family Members of Deaf Children in Relation to the Hearing Status of Their Parents and Siblings. Deafness and Education International, 3, 80-96.

Woolfe, T., Want, S., \& Siegal, M. (2002). Signposts to Development: Theory of Mind in Deaf Children. Child Development, 73, 768-778. doi:10.1002/dei.100

Woolfe, T., Want, S., \& Siegal, M. (2003) Siblings, Conversation, and Theory of Mind in Deaf Native Signing Children. Journal of Deaf Studies and Deaf Education, 340-347. doi:10.1093/deafed/eng023

Zunshine, L. (2011). Style Brings in Mental States. Style, 45(2):349-56. 


\begin{tabular}{|c|c|c|c|c|c|c|c|}
\hline Book & $\begin{array}{l}\text { Number } \\
\text { of Pages }\end{array}$ & Linguistic features & Illustrative content & $\begin{array}{l}\text { Mean Words } \\
\text { per page }\end{array}$ & $\begin{array}{l}\text { Mental state } \\
\text { terms }\end{array}$ & $\begin{array}{l}\text { Emotional state } \\
\text { terms }\end{array}$ & Characters \\
\hline $\begin{array}{l}\text { The } \\
\text { Gruffalo }\end{array}$ & 22 & $\begin{array}{l}\text { End rhyme } \\
\text { Repetition } \\
\text { Imagery e.g. Gruffalo crumble, } \\
\text { scrambled snake }\end{array}$ & $\begin{array}{l}\text { Detailed cartoon style } \\
\text { Closely follows narrative }\end{array}$ & 29 & Know & Afraid & $\begin{array}{l}\text { Animals } \\
\text { Fictional creature }\end{array}$ \\
\hline $\begin{array}{l}\text { Handa's } \\
\text { Surprise }\end{array}$ & 24 & $\begin{array}{l}\text { Repetition } \\
\text { Some vocabulary uncommon to UK } \\
\text { e.g. guava }\end{array}$ & $\begin{array}{l}\text { Detailed cartoon style } \\
\text { Depicts Kenyan culture } \\
\text { Closely follows narrative } \\
\end{array}$ & 4 & $\begin{array}{l}\text { Wonder, } \\
\text { surprise }\end{array}$ & None & $\begin{array}{l}\text { Human, true to life } \\
\text { Animals }\end{array}$ \\
\hline $\begin{array}{l}\text { Arthur's } \\
\text { Tractor }\end{array}$ & 24 & $\begin{array}{l}\text { Ideophones (chugga thrum, thud, } \\
\text { eeek) } \\
\text { Figurative language } \\
\text { Invented / unfamiliar technical } \\
\text { language e.g. sprocket spring } \\
\text { sprigget }\end{array}$ & $\begin{array}{l}\text { Detailed cartoon style } \\
\text { showing background } \\
\text { and foreground } \\
\text { Illustrations show more } \\
\text { than narrative }\end{array}$ & 20 & None & None & $\begin{array}{l}\text { Human, true to life (Arthur) } \\
\text { Fictional (dragon) } \\
\text { Fairytale (princess, knight) }\end{array}$ \\
\hline $\begin{array}{l}\text { Eat Your } \\
\text { Peas }\end{array}$ & 24 & $\begin{array}{l}\text { Repetition } \\
\text { Simple common words }\end{array}$ & $\begin{array}{l}\text { Closely follows narrative } \\
\text { 2D cartoon } \\
\text { Bold colours } \\
\text { Close up images of } \\
\text { characters' expressions }\end{array}$ & 21 & None & Knew, want & Human, true to life \\
\hline $\begin{array}{l}\text { Mrs } \\
\text { Rainbow }\end{array}$ & 32 & $\begin{array}{l}\text { Some complex words } \\
\text { (unanimously, reluctantly, emerge) }\end{array}$ & $\begin{array}{l}\text { Bright and bold colours } \\
\text { 2D cartoon style } \\
\text { Closely follows narrative }\end{array}$ & 38 & Believe, think & $\begin{array}{l}\text { Happy, worried, } \\
\text { excites, glad, sad, } \\
\text { courage, } \\
\text { embarrassment } \\
\end{array}$ & Human, true to life \\
\hline
\end{tabular}


Handa's Surprise (Browne, 2006) Handa sets off to visit Akeyo with a varied basket of fruit. The fruit is stolen piece by piece by a range of animals without her knowledge. She is surprised to find the basket full of tangerines which fell when a goat hit a tree. Akeyo appears delighted with the tangerines, unaware of the previous variety of fruit

\section{$\mathbf{1}^{\text {st }}$ order skills}

Attribute thoughts (cognitive)/ feelings (affective) to others

Pass false belief tasks

Understand that we know information because we have seen it or heard it

\section{The reader will acknowledge:}

Handa is thinking about her friend Akeyo and about the fruits. She looks like she feels happy and excited.

Can predict a person's actions on basis of a person's false beliefs

Identify character's feelings according to whether wishes are fulfilled

\section{$2^{\text {nd }}$ order skills}

Think about what one person is thinking or feelings

about what another is thinking or feeling

Understand that one can have first one emotion and

then a second emotion to the same situation

Handa believes throughout that the basket is still full of the selection of fruit. She does not know that animals have taken the fruit as she hasn't seen it. Later, she does not know about the tangerines, still believing that the basket is full of the initial selection of fruit.

Handa believes she is still carrying the selection of fruit. She carries on to Akeyo's home because she doesn't know the animals have taken fruit.

Handa wanted to take a selection of fruits to Akeyo. At the end she is feeling surprised. She may feel disappointed. Akeyo is delighted with the tangerines and happy with one type of fruit, not knowing about the others

The reader will acknowledge:

Throughout the book Handa is wondering what Akeyo will think / feel about the different fruits / the gift

Handa might feel surprised about the tangerines but happy that Akeyo is happy. She may later feel cross upon finding out that the animals had taken the fruit / confused and left wondering what happened.

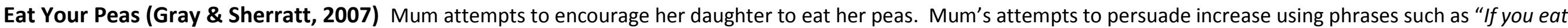
your peas I'll buy you a chocolate factory". The story ends the daughter's exclamation that she will eat her peas if mum eats her brussels sprouts.

\section{$\mathbf{1}^{\text {st }}$ order skills}

Attribute thoughts (cognitive) and feelings (affective)

to others

Identify character's feelings according to whether wishes are fulfilled

\section{2nd order skills}

Think about what one person is thinking or feelings about what another is thinking or feeling

\section{Higher order ToM}

Understanding of lies

Understanding the use of figurative language

Understand concurrent emotions of opposite types

\section{The reader will acknowledge:}

Daisy is becoming more and more cross / Mum is getting more and more frustrated.

Mum's lip "beginning to wobble" means she is becoming upset.

Mum is becoming cross as Daisy will not do what she wants her to do.

\section{The reader will acknowledge:}

Daisy knows that mum wants her to eat her peas and is thinking of ways to encourage her to do so. Mum believes that Daisy will feel persuaded by mum's offers.

\section{The reader will acknowledge:}

Mum is lying about what Daisy will get if she eats her peas. Daisy knows she will not get these things - it is persuasion. The terms 'Little green balls' and "ganging up on her plate"

Mum felt it was ok to persuade Daisy to eat peas but felt differently when Daisy tried to persuade her to eat sprouts. 
Arthur's Tractor (Goodhart,2003) A farmer believes that the strange noises he hears are caused by his tractor but behind him a fairy story unfolds and the noise is created by a princess escaping from a dragon. He is unaware of what is happening in the background as he doesn't see it.

\section{1st order cognitive / affective ToM}

Attribute thoughts (cognitive) and feelings (affective)

to others

Pass false beliefs tasks

Understand now only what people see but how it appears to them

Understand that we know information because we

have seen it or heard it

Understand that beliefs cause people to act in certain ways

Understand that thoughts / emotions are caused by what people think is the case even if it conflicts with reality

\section{Second order skills}

Can judge situation and understand that people

remember, forget, guess

\section{Higher order skills}

Understanding figurative language

\section{The reader will acknowledge:}

The princess is scared of the dragon

Arthur has the false belief that his tractor is making the noises.

Items from the background story (sword, dragon's fire, princess' dress) appear to be things to fix a tractor with

Arthur does not know about the story unfolding in the background because he did not initially see or hear it.

Arthur attributes noises he hears on things surrounding him to faults with the tractor. He continues to concentrate on fixing the tractor because of his fault belief.

Throughout the book Arthur continues along a trajectory that he may not have done if he could see what the reader sees / if he had been told

\section{The reader will acknowledge:}

Arthur has no evidence that the strange noises are made by the tractor - nobody told him but he makes a guess

\section{The reader will acknowledge:}

Use of terms such as "knobble my kneecaps", "bless my blisters", "dollops of dung"

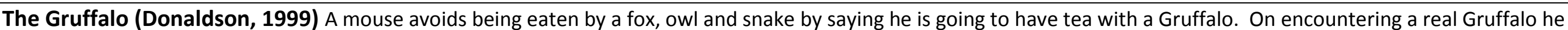

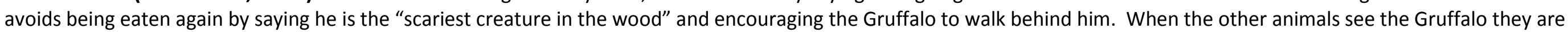

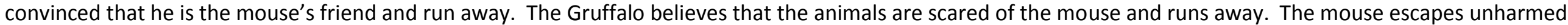




\begin{tabular}{|c|c|}
\hline $\begin{array}{l}\text { First order cognitive / affective ToM } \\
\text { Attribute thoughts (cognitive) and feelings (affective) } \\
\text { to others }\end{array}$ & $\begin{array}{l}\text { The reader will acknowledge: } \\
\text { The owl, fox and snake are thinking about eating the mouse. }\end{array}$ \\
\hline Actions can be predicted on basis of false beliefs. & $\begin{array}{l}\text { We can see that the fox will run away because he believes the mouse. The same is true for the other animals and the } \\
\text { Gruffalo at the end of the story. }\end{array}$ \\
\hline $\begin{array}{l}\text { Understand not only what people see but how it } \\
\text { appears to them. }\end{array}$ & At the start there is no evidence of the Gruffalo but for the animals it appears to be something to be scared of. \\
\hline Pass false belief tasks & $\begin{array}{l}\text { The animals run away feeling scared because he believes the Gruffalo eats roasted fox (owl icecream or scrambled } \\
\text { snake). The animals have false beliefs. }\end{array}$ \\
\hline $\begin{array}{l}\text { Understand that we know information because we } \\
\text { have seen it or heard it }\end{array}$ & $\begin{array}{l}\text { The reader knows that the mouse is lying as he says "Silly old owl, doesn't he know? There's no such thing as a } \\
\text { Gruffalo". However, the other animals do not hear this and do not know. }\end{array}$ \\
\hline $\begin{array}{l}\text { Understand that thoughts and emotions are caused by } \\
\text { what people think is the case even if this conflicts with } \\
\text { reality }\end{array}$ & The Gruffalo thinks that the mouse is something to be scared of. In reality, he is a small, harmless mouse. \\
\hline $\begin{array}{l}\text { Second order skills: } \\
\text { Think about what one person is thinking or feelings } \\
\text { about what another is thinking or feeling }\end{array}$ & $\begin{array}{l}\text { The reader will acknowledge: } \\
\text { The mouse believes that the animals believe there is a Gruffalo. He knows he is doing a good job of tricking him. The } \\
\text { animals believe that the mouse is telling the truth. The mouse believes that the animals feel scared of the Gruffalo. } \\
\text { The mouse knows that the Gruffalo thinks the mouse is the scariest creature in the wood. }\end{array}$ \\
\hline Higher Order skills & The reader will acknowledge: \\
\hline $\begin{array}{l}\text { Understanding strategies to hide deceit and to detect } \\
\text { deceit. }\end{array}$ & $\begin{array}{l}\text { The Gruffalo is suspicious and follows the mouse to "find him out". The mouse knows that if the animals AND the } \\
\text { Gruffalo believe him he will be successful in his trickery. }\end{array}$ \\
\hline $\begin{array}{l}\text { Presentational lies: making oneself look good in the } \\
\text { eyes of others. }\end{array}$ & The mouse claims "I'm the scariest creature in this wood" to the Gruffalo \\
\hline Understanding of lies & $\begin{array}{l}\text { The animals invite the mouse to their homes for lunch because they want to eat him. The mouse lies throughout the } \\
\text { book. He knows he is lying and to ensure that his initial lies (I'm having tea with a Gruffalo) are believed he has to } \\
\text { continue to convince the Gruffalo that the animals are scared of him. }\end{array}$ \\
\hline Multiple embeddings & $\begin{array}{l}\text { The mouse knows that the Gruffalo thinks the animals feel scared of the mouse. At the end, the Gruffalo believes the } \\
\text { mouse believes that the other animals are scared of the mouse. }\end{array}$ \\
\hline
\end{tabular}

Mrs Rainbow (Griffiths, 2006) Bright colours make Mrs Rainbow happy. Her house is brightly painted. The town council instruct her to paint it grey. This impacts on her mood and emotions. When the other people in the village paint their houses bright colours and she is allowed to repaint her house in the colours she likes. 


\begin{tabular}{|l|l|}
\hline $\begin{array}{l}\text { First order skills } \\
\text { Attribute thoughts (cognitive) and feelings (affective) } \\
\text { to others }\end{array}$ & $\begin{array}{l}\text { The reader will acknowledge: } \\
\text { Mrs Rainbow runs through a range of emotions within the book. } \\
\text { Having colourful things in the house make Mrs Rainbow happy } \\
\text { Removing the colour from her home makes her sad and withdrawn }\end{array}$ \\
$\begin{array}{l}\text { Understand now only what people see but how it } \\
\text { appears to them }\end{array}$ & $\begin{array}{l}\text { It appears to Mrs Rainbow that no one likes the rainbow house as the Planning Committee decided the house should } \\
\text { be repainted. }\end{array}$ \\
$\begin{array}{l}\text { Understand that we know information because we } \\
\text { have seen it or heard it }\end{array}$ & $\begin{array}{l}\text { The reader and Mrs Rainbow both know about the council decision because of the letter but the villagers do not } \\
\text { appear to know until they see the house painted grey. }\end{array}$ \\
$\begin{array}{l}\text { Understand that beliefs cause people to act in certain } \\
\text { ways }\end{array}$ & $\begin{array}{l}\text { Believing that others do not like her house makes Mrs Rainbow feel sad. The belief makes her stay indoors. } \\
\begin{array}{l}\text { Identify character's feelings according to whether } \\
\text { wishes are fulfilled }\end{array}\end{array}$ \\
\hline $\begin{array}{l}\text { Second order skills } \\
\text { Think about what one person is thinking or feelings } \\
\text { about what another is thinking or feeling }\end{array}$ & $\begin{array}{l}\text { Buying items for the home at the school fair fulfils her wishes and makes her smile. She is happy in the end when her } \\
\text { Tesire to have a brightly coloured house is fulfilled. }\end{array}$ \\
$\begin{array}{l}\text { Tan describe situations where emotions such as } \\
\text { jealousy, worry, pride, shame, guilt may emerge }\end{array}$ & $\begin{array}{l}\text { The villagers feel proud of their actions } \\
\text { The councillors feel embarrassed to be hugged at the end }\end{array}$ \\
\hline
\end{tabular}


Tricks, lies and mistakes: analysing fiction to exploit Theory-of Mind understanding in deafchildrenforidentifying Theory of Mind concepts within storybooks shared with deaf childrenfor use by Teachers-of-the-Deaf Theory of Mind concept analyzing fiction with Theory of Mind concepts used by Teacher-of-the-Deaf

\section{Abstract}

Recent years have seen a significant interest in Theory of Mind (ToM), the specific groups in which it may be restricted and the opportunities which might enhance or suppress development. -Previous studies have identified gaps in the literature concerning ideas for intervention and strategies which may augment the development of ToM skills. -Published work outside the field-suggests the use of children's fiction to support understanding of ToM for young children. -However, the current body of evidence does not critically appraise the value of picture books in developing the ToM of deaf children or provide any-analysis of the elements of ToM hich they may contain.

This paper considers the opportunities held in children's fiction and details analysis based on a developmental perspective of ToM (Westby \& Robinson, 2014). -The books analysed were chosen by educators of deaf children and researchers in the field. -The opportunity for practitioners and parents alike-to see aspects of ToM in readily accessible fiction is considered with a view to exploiting booksharing for ToM discussion. 


\section{Introduction}

Human beings are complex. -Thoughts and emotions are complicated, abstract and invisible when isolated from the facial expressions, behaviours and words which support their recognition. -As inhabitants of the social world we not only have the challenge of working with the set of thoughts and emotions that we hold but also in understanding the thoughts and emotions of others.- When we communicate with others, people who are adept at navigating social situations are easy to recognise as are those who find navigating the social world father-more perplexing.- However, whilst these skills hold such importanceare pivotal to our interactions, most people use them implicitly and without conscious thought. This paper considers the role of those surrounding deaf children, whose skills in understanding the thoughts and feelings of others and themselves may be more vulnerable to

development

In academic literature, understanding the thoughts and emotions of ourselves and others is labelled Theory of Mind (ToM), a phrase coined by Premack and Woodruff (1978) and often described as "mindas 'mind-reading"-_or "or 'perspective taking"-.'.-The importance of the topic cannot be overlooked given the al thensidering that refining and developing ToM skills can support skills such as the ability to empathise with others (Peterson, 2015), the making of reciprocated friends and prevention of friendlessness (Fink, Begeer, Peterson, Slaughter \& de

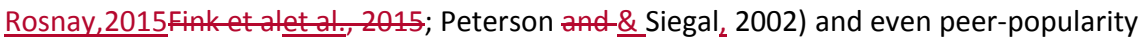


(Peterson, O’Reilly \& Wellman, et al__2016z). -ToM has-is been suggested-considered to be vulnerable within Disorder (ASD) initially (Baron-Cohen et a, Leslie \& Frith, let al. 1985; Wimmer \& Perner, 1983), deafness (Peterson \& Siegal 199ㄷㄷ, Peterson \& Siegal 1998; Russell et alet al. 1998O'Reilly et al. 2014) and a growing vidence base suggests links to a range ofother aetiologies (Bodden et alet al. 2009; Byom \& Turkstra, 2012; Bánrétiet al_.2016; Pollettia et aletal. 2011). - Unlike the connection between ASD and ToM, the connection between deafness and ToM is indirect and hinged on a number of factors. A robust evidence base demonstrates that the impact of the environment-and those whothose who surrounding the deafindividual form the connection. -The importance of shared common language in the home (Peterson and_\& Siegal 1995; Courtin 2000; Woolfe-eta, Want \& Siegal, let al_2002; Schicket a, de Villiers, de Villiers \& Hoffmeister, let at. 2007; Courtin and \& Melot 2005), exposure to conversations about mental states (Moeller \& Schick 2006; Ruffman et alet al. 2002 L, and-as well as environments and people who facilitate '-closeness'-" of communicative experiences (Woolfe \& Smith, 2001; Woolfe et alet al. 2002; Woolfe et $a_{L}$ Want \& Siegal, 2003) have been seen to be key to deaf children's ToM development.

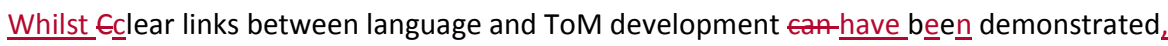
but a more complex and interwoven situation is shown, in-emerging evidence suggests a complex and interwoven relationship with deaf children's ToM that the understanding of FoM is theability predictinger of deaf children's-peer social skills over and above other factors such as age, gender, language ability and the impact of being a native or late-signer (Peterson et a, Slaughter, Moore \& Wellman, let al. 2016b). 
The developmental process followed by children whose skills are emergingof ToM in children is now well understood with clear frameworks liten describedescribing the potential subskills involved and typical ages at which this might typically developof development (Wellman \& Liu 2004; Westby \& Robinson 2014; Peterson Wellman \& Slaughter, 2012). -The idea that ToM is a unitary construct (iei.e. the dimensions and aspects of ToM being one and the same) and that itemerges at the age of 4/5 between the ages of four and five years has now given way to the understanding of ToM as a multidimensional construct (Westby \& Robinson, 2014). This multidimensional construct involvingesing the cognitive (thoughts) and affective (feelings) domains domains (Westby \& Robinson 2014), one that pertains to self (interpersonalintrapersonal) and others (intrapersonalinterpersonal) (Westby \& Robinson, 2014). It is now-and one Which-acknowledgeds that ToM does not suddenly emerge but involves the-precursors which can be seen in infancy (Baillargeon et a, Scott \& Helet at., 2010; Kovács et alet al. 2010; Surianet a, Caldi \& Sperber, let al.2007). A review from Dvash and \& Shamay -Tsoory (2014) supports the eoncept of multidimensional construct of ToM as a multidimensional by identifying the neurophysiological / neuroanatomical functioning of the brain when exposed to different elements of ToM and empathy. -This suggests a need for those who teach deaf children to have a working knowledge of its multidimensionality in the best interests of enabling opportunities for deaf children. It is hoped that the framework discussed later within this article will support the opportunities for applied teacher knowledge. 
Literature in the field has called for practical and meaningful interpretations of research evidence which relate to classroom practice with deaf children (Chilton \& Beazley, 2014; Beazley \& Chilton, 2015; Chilton \& Beazley, under review; Swanwick \& Marschark, 2010). Outside of Deaf Education, a substantial-body of evidence is beginning tohas considered the connections between reading fiction and ToM. A range of studies Studies note that adults who frequently read fiction function at an advanced level on measures of empathy and social cognition (Maret at, Oatley, Hirsh, dela Paz \& Peterson, 2006et al. 2006; Maret $a_{L}$ Oatley \& Peterson, tet al. 2009, Black \& Barnes 2015). -There are several contrasting ideas with respect to this. -The first is that reading fiction has the potential to enhance ToM not due to the process of reading per se but due to the meta-linguistic material embedded within the books. -This is based on the premise that fiction contains characters, language or plots which are conducive to enabling readers to utilise their ToM skills.- Within an adult population, Kidd \&and Castano (2013) evidence the effect of reading "'literary fiction'”(described as writerly and polyphonic) on the development of ToM skills. -Those who read literary fiction (in comparison to those who read non-fiction or, popular fiction or and those who did notnon-readers partake in a reading activity) showed ian-mproved performance on ToM tasks.- The work of Kidd \& and Castano (2013) and Zunshine (2011) suggests that the potential forreading fiction to a primer for ToM development althoughthere is a question of '-'style"-' and it is unclear as to how long-lasting the effects may be (Kidd \& Castano, 2013).--Considering empathy as one specific component of ToM enables us to see links between the development of empathy and reading fiction. Bal \& and Veltkamp (2013) and Stansfield \& and Bunce (2014) suggest that reading fiction enables readers to become more empathic than those who read non-fiction, but only when they are emotionally transported into the story. -This is an important consideration for professionals 
in Deaf Education as a wealth of literature has evidenced the vulnerability of some deaf children to the development of empathy (Netten, Rieffe, Theunissen, Soede \& Dirks, et alet al., 2015); Peterson 2016c) and furthermore the development of empathy in deaf children has been correlated with the development of the wider concept of ToM (Peterson, 2016c).:

The second idea related to the meta-linguistic features of fiction is the inclusion of mental states within the book. -These mental states may be-present as terms in the printed narrative (e.g. know, believe, guess, wonder) the book'-" when the book is shared dialogicallyin dialogic reading. In terms of the presence of mental state terms within the printed narrative, Dyer, Shatz and Wellman-et alet al. (2000) found that children's books increase their reference to mental states according to age-withfor example books aimed at 5-6 year olds includeing a higher frequency of and wider variety of mental state references compared with those aimed at 3-4 year olds. -Based on the inclusion of mental state terms, the findings indicate the potential ofsuggested storybook reading as potentially rich for ToM development. Meanwhile,Adrian, Clemente, and Villanueva Adrian ald (2007) haverevidenced that maternal use of cognitive verbs in storybook reading correlated to their children's later performance on ToM tasks.

Inconsidering the pes of books which might feasibly suit this type oflearning for children who may need this type of support, Westby \& and Robinson (2014) and -Nikolajeva (2013) suggest a range of books and consider the role of booksharing to enhance ToM development. - With a specific focus to enhancing ToM skills in deaf children, Stanzione \& 
and Schick (2014) suggest) suggest that books such as "'Little Red Riding Hood"', as have potential to enhance children's exposure to dual mental representations although. Whilst useful as a usefulstarting point, Stanzione \& and Schick (2014) did not analyse-the specific ToM components in such books were not analysedormake recommendation as to how practitioners might pullonsuch themes. -Concluding a study which specifically considered the need to enhance ToM skills in deaf children, Jones, Gutierrez and Ludlow et alet al. (2015) discussed the need for more-research into the value of picture books as a mode of intervention with deaf children.

tooking atConsidering the links between ToM and fiction reading from a different angle, there is evidence to suggest that refined abilities in ToM help the reader to understand the deeper meaning and inference of the book.- To exemplifyExemplifying this, Holmer, Hiemann and Rudner (et alet al. (2016) found that there was-a positive association between ToM and reading comprehension abilities and ToM in deaf children. The study identified a correlation between being a competent reader and ToM ability.. In this study, Swedish Sign Language comprehension did not correlate to a more advanced ToM This is lin contradiction which may contrastcontrasting with to much of the-earlier research (by whom?Courtin \& Melot, 2005) which has shownshowed that access to native sign supports ToM development when children are tested on false belief tasksłt. —Similarly, Pelletier \& 
appreciate what a person is thinking/feeling about what another person is thinking / feeling) predicted a hearing child's ability to understand Aesop's Fables (folktales characterised by themes of morality and deception). - It was suggested thatemphasised the importance of mental state awareness was important in giving enabling children the ability to be able-to judge character, intentionality and deeper messages within the story.

The evidence suggests a close relationship between reading fiction and ToM. -Concepts of ToM are suggested to be deeply embedded in the context of books with potential to be utilised to support children's ongoing development but ToM is also suggested to be needed to truly understand the story.- Whereas the adult UK population demonstrates a-great diversity in prevalence of reading (Booktrust 2013), assumption might assume that children have more regularity in exposure to fiction reading as this forms part of both the primary and secondary curriculum. The critical point when considering the experience of deaf children is that booksharing may hold the key to supportingln situations where ToM is seen to be vulnerable (e.g. for deaf children) the presence of ToM concepts in shared books may support development although it is recognised potential gains Tom development which (unlike the majority of hearing children) has been seen to be vulnerable. The value of such booksharing may be influenced by the type of books shared and the approach taken by the sharer. -This study paper considers the opportunity to use children's fiction to enhance ToM and-considers a framework for picking outidentifying the elements of ToM from thewithin children's picture books which can be explored with deaf 
children as developmentally appropriate and beneficial-in order to support their progression of ToM skills.

The questions are: paper considers the following:

1. $\underline{\text { Can }}$

1. Using the ToM framework presented-in Westby \& Robinson (2014) Development of ToM as maybe used a framework forto identifying ToM within children's fiction?

1. What elements of ToM can be found in children's fiction storybooks storyook fiction shared with deaf children? ?

- How might those who share books with deaf children exploit elements of ToM in popular fiction? 


\section{Methodology}

Two previous reports (Beazley \& Chilton 2015; Chilton \& Beazley 2016, under review)

discuss a project which considers the role of educators of deaf children, their understanding

of ToM development and the activities they undertakestrategies used when undertaking

Commented [A3]: Undertake used twice, consider rephrasing. shared reading. -Five Teachers of the Deaf (-ToDs) within that study were asked to select books to read with deaf children in a booksharing activity. -ToDs were asked to select books which focussed on "thoughts and beliefs", excluding and were asked not to useinclude-books from a-book schemes which is are useddesigned to support emerging reading skills. -Teachers were provided with examples of books to support thinking but selected their own choices (which could be one of the examples or a different book). This was reported in Beazley and Chilton (2015). This study paper reports on the books shared with deaf children by ToOs from that initial project. The ToDs shared books with children they regularly work with aged between 4 and 8 years old, a time where children are typically displaying an increasing understanding of ToM (Westby \& Robinson, 2014). -All the children and ToDs used English as their first language and. Fthe teachers worked in a range of settings including peripatetic services, resource bases in mainstream schools and in a school for the deaf.

This paper considers seeks to consider-the range of ToM concepts which may be-evident in the books chosen, used within the previously reported studies (Beazley \& Chilton 2015;

Chilton \& Beazley 2016, under review). considering the development of ToM at this stage of childhood. The teachers chose these books with the intention of sharing them with children they regularly work with who use English as a first language.

Commented [A4]: How did the teachers choose the books because they are popular, or because they are recommended readings by the schools/ministry or education agencies/etc.? Although this may have been reported in the articles cited in this paragraph, for the purpose of this manuscript, I would like to know how these five books were the ones used by the teachers, and how these five books were the ones used by the teachers, and
hence, analysed. Did the teachers choose the books because of their understanding of ToM?

Also of interest - how did the teachers use these books with the children? Independent reading, or shared reading, or other methods? 
Analysis

Five books are the focus of discussion for this paper. -The books were read several times by the researcher to gain a good-grasp of the theme and subject matter of the book.- Each book was then analysed for the following: linguistic features, number of pages, illustrative content, mean words per page, mental and emotional state terms and characters.- This enabled the researcher to have an overview of the book before considering the-potential ToM concepts.

The basis for analysis of the ToM concepts in the books was derived from Westby \& and Robinson (2014) who suggest a framework for understanding subskills of ToM within the cognitive and affective domains and separate these into a developmental of advancement offramework of ToM e.g. pre ToM skills, first order, second order and higher order skills. An adapted (with permission) overview from Westby \& and Robinson (2014) is shown here.andt The author encourages readers to consult the original work for a more comprehensive understanding. 


\begin{tabular}{|c|c|}
\hline $\begin{array}{l}\text { 4/5Four/five years } \\
\text { First order skills } \\
\text { Understanding } \\
\text { thoughts and } \\
\text { emotions }\end{array}$ & $\begin{array}{ll} & \text { Attribute thoughts (cognitive) and feelings (affective) to } \\
\text { - } & \text { others } \\
\text { Pass false belief tasks } & \text { Understand not only what people see but how it appears to } \\
\text { them } & \frac{\text { Understand that we know information because we have seen }}{\text { it or heard it }} \\
& \text { Understand that beliefs cause people to act in certain ways } \\
& \text { Understand that thoughts and emotions are caused by what } \\
& \text { people think is the case even if this conflicts with reality } \\
& \text { han describe situations where non-social emotions such as } \\
\text { emotions such as disgust and worry may emerge. }\end{array}$ \\
\hline $\begin{array}{l}\text { 6-8Six to eight years } \\
\text { Second order skills } \\
\text { Expanding } \\
\text { understanding of } \\
\text { range of thoughts and } \\
\text { emotions }\end{array}$ & $\begin{array}{l}\text { Thinking about what one person is thinking/feeling about } \\
\text { what another is thinking/ feeling (e.g. A believes that B } \\
\text { believes; A knows that B feels) } \\
\text { Understand that one can have first one emotion and then a } \\
\text { - } \frac{\text { second emotion to the same situation }}{\text { Can judge situation and understand that people remember, }} \\
\text { forget, guess } \\
\text { Can describe situations where social emotions (requiring } \\
\text { understanding of mental states of others) such as jealousy, } \\
\text { pride, shame, guilt may emerge }\end{array}$ \\
\hline $\begin{array}{l}8+\text { Eight years plus } \\
\text { Higher order skills }\end{array}$ & $\begin{array}{l}\text { - Multiple embeddings e.g. "She thinks that her mother knows } \\
\text { - } \frac{\text { that her brother hopes his girlfriend will want the gift" }}{\text { Recognize and understand lies, sarcasm, social faux pas, }} \\
\text { - } \frac{\text { figurative language, idioms }}{\text { Understand that people may use strategies to hide deceit and }} \\
\text { - } \frac{\text { to detect deceit }}{\text { Presentational lies (making oneself look good in the eyes of }} \\
\text { - others) } \\
\text { Understand that one can have concurrent emotions of } \\
\text { opposite types }\end{array}$ \\
\hline
\end{tabular}

Precis from Westby and\& Robinson 2014 (with permission)

\section{Domains of Theory of Mind (Westby \& Robinson, 2014)}

\begin{tabular}{|l|l|}
\hline \begin{tabular}{l} 
Cognitive ToM: \\
\multicolumn{1}{|l|}{}
\end{tabular} & attribute mental states (e.g. know, believe, wonder, guess) \\
\hline Affective ToM: & recognise emotions \\
\hline Interpersonal ToM: & $\underline{\text { cognitive and affective ToM for others }}$ \\
\hline Intrapersonal ToM: & $\underline{\text { cognitive and affective ToM for self }}$ \\
\hline
\end{tabular}

Westby and\& Robinson (2014) (with permission) 
Appendix 1

The developmental trajectory outlined in Westby \& and Robinson (2014) was used as a theory-driven code (Boyatzis, 1998), -enabling the researcher to consider elements of the books which relate to the order of ToM skills (iei.e. first $1^{\text {st }}$ order through to higher order). The books were coded by the author, noting each possible thread of ToM with the potential for exploitation by those who teach deaf children.- It is acknowledged that other readers of the books may highlight different aspects than have been reported here (as we all inference meaning to the written word).- This is discussed later in the limitations but this is meant as a However, the paper here presents a starting point from a researcher / practitioner who is familiar with developmental aspects of ToM and children's literature and has previously reported on aspects of ToM in -'Sstrange Sstories' (Chilton \& Beazley, 2014). 


\section{Results}

\section{$\underline{\text { Overview of books }}$}

The included books are readily available in the UK and are used within primary settings nationallyin the United Kingdom.- It is expected that readers of Deafness and Education International are familiar with some or all of the books.- An overview of the style of each book can be seen in Appendix $\underline{1 z}$

-Appendix $1 z$ -

\section{Analysis of ToM content}

All books within the study included a depth and variety of ToM concepts. -The books incorporated these features in a multitude of ways. -Two of the books demonstrated the opportunity to discuss first and second order concepts. -Three of the books demonstrated the opportunity to discuss first, second order and higher order concepts. The books were not analysed for concepts considered to be pre-cursors to ToM.

\section{-Appendix $\underline{2} 3-$}

One of the books within the study; The Gruffalo; by Donaldson (1999), demonstrates a plethora of higher order elements of ToM, including the opportunity to discuss multiple embeddings, the understanding of strategies to hide and detect deceit and presentational lies. Whilst Eat Your Peas (Gray \& Sherratt, 2007)_was linguistically simple and visually clear, it lent itself to discussions arounddiscussing lies and persuasion and may be used to invoke discussion including higher order elements. -Within Arthur's Tractor (Goodhart, 2003) there was the opportunity to exploit the illustrative content which demonstrated that Arthur did not know about the story which was unfolding behind him. 
Handa's Surprise (Browne, 2006) and Mrs Rainbow (Griffiths, 2006) included opportunities to promote discussion of first and second order ToM.- Whilst Handa's Surprise is regularly used in UK primary setting for vocabulary work due to the range of animals and tropical fruits, the opportunities for ToM--based work appear integral to the book with Handa continuing on the journey with her the false belief that she was still carrying the range of fruits.

Whilst research has shown the potential for parental use of mental state terms in augmenting ToM understanding (Moeller and_\& Schick, 2006) the books in this study did not rely on this to overtly display the ToM concepts. -For example, in The Gruffalo, only one 1 emotional state term (afraid) and one1 mental state term is used (know). HoweverHowever, this book gave rise to discussion fromincludes a range of ToM concepts from first order up to higher order levels of ToM concepts-and presented as the most cognitively complex book when considering such concepts. -Mrs Rainbow included the most words per page, more mental and emotional state terms and comparatively more complex words that other books in the study. -However, these features of the book did not correlate to a more extensive range of ToM concepts within the book. -Books with relatively fewer words per page (e.g. Handa's Surprise) still gave the opportunity for discussion of ToM concepts with a range of second order elements being integral to the book. 


\section{Discussion}

In support of earlier theories, it appears that picture-book fiction contains content that could be used to stimulate the development of ToM (Westby \& Robinson 2014, Stanzione \& Schick 2014). All books contained plots and storylines-conducive to discussing ToM with deaf children and these ranged across first order, second order and higher order concepts. -Whilst previous studies identified the potential of booksharing, this study offers a meta-analysis of five 5 choices-examples used with deaf children by applying knowledge of ToM concepts (Westby \& Robinson, 2014).

A dichotomy between research and practice in ToM and deaf children has been suggested in the literature (Swanwick and_\& Marschark 2010, Beazley and \& Chilton 2015) and emerging research evidence evidences-demonstrates the importance of teacherknowledge of developmental ToM as a subject specialism for practitioners who work with deaf children (Chilton and \& Beazley, under review). The outcomes of this study therefore $\in$ This paper acknowledges that cognitively complex ideas are stored in picture books designed for young children. The paper demonstrates an be seen to have multiple purposes - thean opportunity to support practitioners inln establishing a starting point for identifying ToM themes in picture-book fiction, the hope theit is hoped that practictioners will continue they will goonto recognise ToM these-themes in other books and work with others intent onin doing so (e.g. parents, mainstream teachers) and the acknowledgement that cognitively complex ideas are stored in picture books. -The most cognitively advanced book in terms of ToM concepts (The Gruffalo) displayed several themes which would be considered within the Westby \& Robinson (2014) framework as developing as higher order skills, aged 8 and beyond -beyond. -However, this book is regularly used with children in early--years settings and, by the age of 8 , children and teachers have generally progressed to more linguistically challenging reading
Commented [A6]: Does this refer to previous articles by Beazley \& Chilton 2015; Chilton \& Beazley 2016, under review; or, it refers to the general notion of using fiction to develop ToM skills? 
materials. We would suggest that forfor some older deaf children there may be a place for the use of texts with accessible vocabulary for older children if the intended outcome is to improve ToM skills and the content within the book can be guaranteed to be richly exploited.

Whilst there is a wealth of knowledge that maternal input of mental state terms is closely correlated to later success with ToM based tasks (Ruffman et alet al., 2002; de Rosnay \& Hughes, 2006; Symons et alet al. 2006, Laranjo, Bernier, Meins \& Carlson, 2010, Moeller \& Schick, 2006), there was no correlation between high levels of mental state and emotional state terms and opportunity for discussion of ToM concepts within the books in this study. -This sits in agreement with previous-research from Adrian et alet al. (2007) whoidentified where that mothers' use of cognitive verbs in storbook readingwhen sharing wordless picture books had a positive correlation to children's later performance on ToM tasks. -The study suggests that the use of as the mothers were looking at-wordless picture books and therefore nomeant that mothers did notł relying on the inclusion of cognitive verbs within the written text of the story. Similarly, Evidence from-Peskin \& Astington (2004) compared a book (Rosie's Walk) which had been adapted to include explicit metacognitive verbs with a version that did not include such metacognitive verbs. The control group (without explicit metacognitive verbs) actuallyexceeded the group with metacognitive verbs on later false--belief tasks. -It was suggested that this may be because the control group had to actively construct their own interpretation of the stories. -As Narvaez- (2002) notes, that there is an the integral role of the adult in identifying inference and supporting the child's ability to construct meaning. The importance of teacher subject-knowledge of ToM is therefore keyThis illustrates the critical nature of teacher subject-knowledge of ToM L ToM (Chilton and \& Beazley, under review).

The variety of approaches used in booksharing with deaf children is noted by- Swanwick \&-and Watson (2007) who found that families using spoken language focused on the features of the text and had less inclination to use the book to promote wider knowledge. - History has warned us-of 
the damaging effect of simplifying conversations with deaf children (Woods et alet al., 1986). andin spite of Tthe need to ensure ease of communication must be balanced with the vital rolesand we may begin to apply this warning to the vital roles that those around the child have in supporting social cognition. Whilst 'strategies for intervention' may be discussed in the field ¥ethere are a selection of books, readily available amongst many others, which already include a range of opportunities for parents and teachers alike to enhance children's ToM understanding.

Some of the books within the study are highly acclaimed in the UK (TES, 2015; The Guardian, 2014). It is unclear whether this is because fas in The Gruffalo)-complex elements of ToM form such an integral part of the plot (as in The Gruffalo). -It is possible that a depth of ToM concepts supportsupports a book's ability to be read and reread with discussion taking shape in different ways. -The introduction to this studypaper discussed Kidd \& Castano's (2013) research which identifies "_literary fiction"' away from popular fiction. -There is room for debate as to whether this extends to children's literature. Whilst this paper considers the opportunities in texts for primary aged deaf children there is clear opportunities in texts for older children, in working with a range of specialist teachers we are aware of suitable possibilities up to secondary level. -Considering books for older primary readers such as Esio Trot (Dahl, 1991) and books from the secondary curriculum such as Stone Cold (Swindells, 1995) (in discussion withsuggested by Angela Mather, Feacher of the DeafToD) may provide the opportunity to extend this work. -Whilst ToM is not an area that is referred to explicitly within U.K. curriculum, it is a prerequisite to many elements that lie-therein such as to be able to infer when reading or to anticipate the answer sought by the examiner within assessments. -Whilst practitioners and families find ways to work with deaf learners to enable access to reading materials from the secondary curriculum there may the underlying opportunity to use them to exploit ToM understanding. 
tt is important to recognise that, whilst Whilst books give a permanent and physical representation of ToM, it is important to recognise that it existsthe potential to work on social cognition through otherexists in a variety of mediums. -Black and \& Barnes (2015) discuss the impact of TV drama viewing on the development of ToM. -They found that people who viewed TV drama performed significantly better on the-_"-Reading the mind in the eyes'”- task than those who viewed a documentary. -This suggests that it is not the medium (e.g. books, films) which may aid ToM development but it the opportunity to see the embedded ToM themesembedded therein. As we move towards a sophisticated and developmental understanding of ToM it is hoped that those around deafthe children will find examples in the ordinary and everyday world.- It is how wethose examples are exploited that is those examples which is likely to make the difference.

\section{Conclusion}

All five books with the studydiscussed within this paper showed evidence of the inclusion of ToM concepts fromincluding first, second-order and to higher--order concepts demonstrating thedemonstrating the epportunity topotential that 'off the shelf' fiction has in enhancing-enhance deaf children's TOMTOM by using readily accessible fiction. The developmental framework developed-by Westby and Robinson (2014) proved to be an effective overviewin supportingsupported the identification of ToM concepts hich may to support practitionef understanding of hat may be presentin books which had been shared with deaf children. Frameworks such as this may-and could support Teachers of the DeafToDs as a form of aide memoir and- the model of analysing children's fiction for ToM concepts could serve as a basis forenable others to select books with ToM contents. -The model presented here may also support practitioners to consider how they might exploit concepts within a book that is already in use in the classroom. 
Future directions may include consideration of books suitable for older children including books which form part of the secondary curriculum. -Further practice-centred work with deaf children is required to understand the impact that this form of shared reading may have on the progression of deaf children's skills and endeavours in the social world. -The consideration of how practitioners work with older deaf children and adolescents is sparse within the literature but measures which take into account the multidimensional and holistic nature of ToM are beginning to emerge in the litere-(Hutchins, Allen \& Schefer, 2017) and may be used in conjunction with focussed booksharing to evidence progress that deaf children and young people are able to make with the type of highly specialised support-discussed here.

Parents and practitioners who work with deaf children in the UK are now challenged not only to focus on the development of spoken or signed language but to work within the subtlety of how-that developing language-is applied. -With a noted lack of clarity as to how ToM should be assessed in deaf children (Beazley \& Chilton, 2015) there lies the risk that it can appear intangible and abstract in practice. However, as theory discusses the move from a unitary construct to a multidimensional construct, practice must move too.- The move for practice is to understand and see ToM in its multidimensional form (affective / cognitive; pre--ToMm $m$ to higher order, intra/interpersonal ToM skills) and in a multitude of settings and mediums. - Whilst this paper $\underline{\text { enables readers to see a tangible representation of ToM concepts identified in books shared with }}$

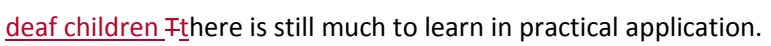




\section{References}

Adrian J.E., Clemente, R.A. \& Villanueva ${ }_{2}$ L. (2007). Mothers' Uuse of $\underline{\text { Ccognitive }}$ Sstate $\underline{\text { Vverbs in }}$

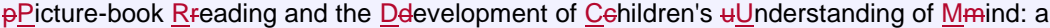

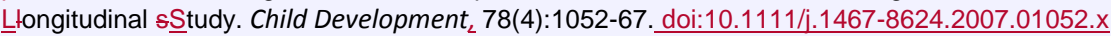

Baillargeon, R., R. Scott, \& and Z.He- ZA. (2010). False-Belief Understanding in Infants.

Trends in Cognitive Sciences, 14-(3): 110-118. doi: 10.1016/j.tics.2009.12.006

Baron-Cohen, S.,_A. M. Leslie \&, and U. Frith U. 1985. Does the Autistic Child Have a "-Theory of Mind'”-? Cognition, 21: 37-46.

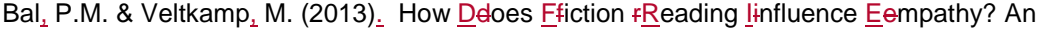
Eexperimental linvestigation on the Rfole of Eemotional Ttransportation. PLoS One ${ }_{1} \cdot 2013 ; 8(1)$ e55341:e55341. doi: 10.1371/journal.pone.0055341.

Bánréti Z., Hoffmann L. and \& V. Vincze V. (2016). Recursive Subsystems in Aphasia and Alzheimer's Disease: Case Studies in Syntax and Theory of Aind. Frontiers in Psychology. doi: 10.3389/fpsyg.2016.00405

Baron Cohen, S., A.M. Leslie and U. Frith (1985) Does the autistic child have theory of mind? Cognition (21), $37-46$ doi: $10.1016 / 0010-0277(85) 900228$
Formatted: Font: (Default) Verdana, $10.5 \mathrm{pt}$, Font color: Custom Color(RGB $(6,69,173))$, Hidden 
Beazley ${ }_{L}$ S. \& Chilton, H.(2015). The Voice of the Practitioner: Sharing Fiction Books to Support the Understanding of Theory of Mind in Deaf Children. Deafness \& Education International-Deafness \& Education International, 17-(4):-231 - 240. doi:10.1179/1557069X15Y.0000000010

Black, J. \& Barnes, J. (2015). The Eeffects of Rfeading Mmaterial on Śsocial and Nanon-S_social CEEognition.; Poetics, Volume 52, October 2015, Pages 52: 32-43.,ISSN Q304-422X,doi:10.1016/j.poetic.2015.07.001.

Bodden, M., R. Dodel, \& E. Kalbe E. (. 2009).. "Theory of Mind in Parkinson's Disease and Related

Basal Ganglia Disorders: A Systematic Review." Movement Disorders 25 (1): 13-27.

doi: $10.1002 / \mathrm{mds} .22818$

Booktrust (2013) Reading ㅂhabits Śsurvey 2013-. A national survey of reading habits and attitudes to books amongst adults in England http://www.djsresearch.co.uk

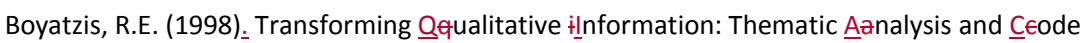
Dedevelopment. Thousand Oaks, London,\& New Delhi: SAGE Publications.

Browne E. (2006) Handa's Surprise. Walker Books ISBN-10: 0744536340

Byom, L., \& Turkstra, L.(2012). Effects of Social Cognitive Demand on Theory of Mind in Conversations of Adults with Traumatic Brain Injury. International Journal of Language and Communication Disorders, 47(3): 310-21. doi:10.1111/j.1460-6984.2011.00102.x.

Chilton, H. \& Beazley S. (2014) Theory of Mind: Are There Wider Implications From Working With d/Deaf People? Disability and Society, 29(2): 184-197. doi:10.1080/09687599.2013.816623 
Chilton, H. \& Beazley S. (under review). Reading the Mmind or Oenly the Sstory? Sharing fiction books to support Theory of Mind development in deaf children.

Courtin, C. (2000). The limpact of $\underline{S}$ sign Lltanguage on the $\underline{C} \in$ ognitive Delevelopment of $\underline{D}$ deaf CEhildren: The case of theories of mind. Journal of Deaf Studies and Deaf Education, 5, 266-276. ISSN-1081-4159

Courtin, C. and \& Melot, A.M. (2005)., Metacognitive development of deaf children: lessons from the appearance-reality and false belief tasks. Developmental Science, 8: 16-25. doi: 10.1111/j.1467. $7687.2005 .00389 . x$

Dahl _R. (1991). Esio Trot. Penguin Books Limited (UK), 1991

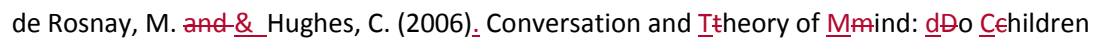

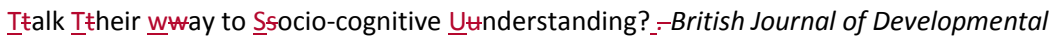
Psychology, 24: 7-37. doi: 10.1348/026151005X82901

Donaldson, J. (1999). The Gruffalo. Macmillan Children's Books ISBN: 9780230747937

Dvash ${ }_{L} J_{.}$\& Shamay-Tsoory S. $_{\underline{.}}$ (2014). Theory of Mind and Empathy as Multidimensional Constructs: Neurological Foundations. Topics in Language Disorders $L_{L^{-}}$34(4):282-295. doi:

10.1097/TLD. 0000000000000040 
Dyer J., Shatz M. \&, Wellman H. (2000). Young EChildren's $\underline{S}$ storybooks as a Sssource of Mmental s. State linformation,-. Cognitive Development, Volume-15, Issue (-1):-,January-March 2000, Pages-17-37.- ISSN 0885-2014, doi: 10.1016/S0885-2014(00)00017-4.

Fink, E., Begeer, S., Peterson, C.C., Slaughter, V. \& de Rosnay, M_-2015). Friendlessness and Theory of Mind: A Prospective Longitudinal Study. British Journal of Developmental Psychology, 33(1):1-17. doi:10.1111/ bjdp.12060.

Goodhart _P. (2003). Arthur's Tractor. Bloomsbury Publishing PLC ISBN: 0747564787

Grey, K. \& Sherratt, N. (2007). Eat Y łour Peas . Random House Children's Publishers UK, ISBN10 1862302324

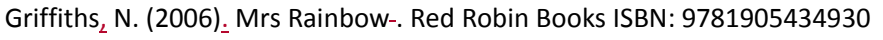

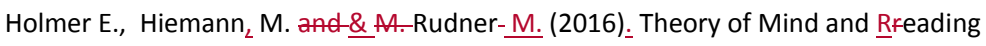
CEomprehension in deaf and hard-of hearing signing children. Frontiers in Psychology, 7, Article 1 854) doi:10.3389/fpsyg.2016.00854 
Jones A., Gutierrez R. \& , Ludlow, A., (2015). Confronting the Language Barrier: Theory of Mind in Deaf Children. Journal of Communication Disorders $,-56,47-58$. doi: 10.1016/j.jcomdis.2015.06.005

Kidd, D.C. \& Castano E. (2013). Reading Literary Fiction Improves Theory of Mind. Science, 342: 377-380. -doi: 10.1126/science.1239918

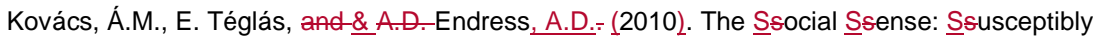

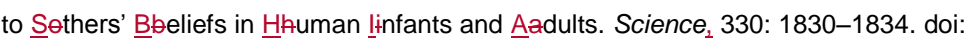
10.1126/science.1190792

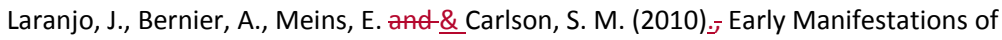
Children's Theory of Mind: The Roles of Maternal Mind-Mindedness and Infant Security of Attachment. Infancy, 15: 300-323. doi: 10.1111/j.1532-7078.2009.00014.x

Mar, R. A., Oatley, K., Hirsh, J., dela Paz, J. andㅌP Peterson, J. B. (2006). Bookworms ㅌyersus ANerds: Exposure to Ffiction $\underline{V}$ wersus $\underline{N}$ non-fiction, Dedivergent $\underline{A} a s s o c i a t i o n s \underline{W} \underline{W}$ ith $\underline{S} s o c i a l \underline{A} a b i l i t y$, and the Sssimulation of Ffictional $\underline{S}$ social Wworlds. Journal of Research in Personality ${ }_{\llcorner} 40(5): 694-712$, doi: $10.1016 /$ j.jrp.2005.08.002 
Mar, R. A., Oatley, K. and \& Peterson, J. B. (2009). Exploring the 나ink Bbetween Rfeading Ffiction and Eempathy: Ruling out lindividual Dedifferences and Eexamining

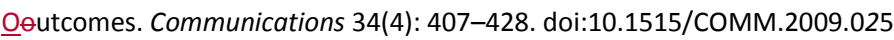

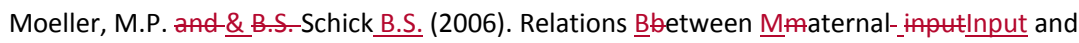

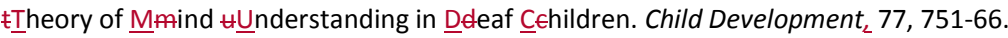
doi: 10.1111/j.1467-8624.2006.00901.x

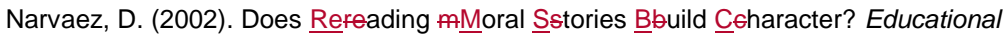
Psychology Review, 14, 155-171. doi:10.1023/A:1014674621501

Netten, A.P., Rieffe, $C_{\underline{.}}$, Theunissen, S.EPM, Soede, W. \& ,Dirks E., et alet at. (2015tL. Low Empathy in Deaf and Hard of Hearing (Pre)Adolescents Compared to Normal Hearing Controls. PLoS $O N E_{\llcorner}$10(40). doi: 10.1371/journal.pone.0124102

Nikolajeva, M. (2013). Picturebooks and Emotional Literacy. The Reading Teacher ${ }_{L}$ Volume 67, Issue 4, 67(4):pages 249-254-._doi:ĐO1:10.1002/trtr.1229

O'Reilly, K., Peterson, C. C., \& Wellman, H. M. (2014). Sarcasm and Aadvanced Ttheory of Mmind Utunderstanding in Cehildren and Aadults with Pprelingual Deleafness. Developmental Psychology, 50(7), 1862-1877. pOtdoi: 10.1037/a0036654 
Peskin J.__\& -Astington ${ }_{L}$ J.W .- (2004). The Eeffects of Aadding Mmetacognitive Lltanguage to $\underline{\text { Sstory }}$ Ttexts. Cognitive Development_, 19 :-253--273. -doi: 10.1016/j.cogdev.2004.01.003

Peterson, C. C. and \& Rfejected Ppreschoolers. British Journal of Developmental Psychology ${ }_{L}(20) 205-224$ doi:10.1348/026151002166415

Peterson, $C_{\underline{.}}$ (2015). Empathy and Theory of Mind in Deaf and Hearing C $\in$ ehildren . Journal of $\underline{D}$ deaf Sstudies and Dedeaf Eeducation. 21 (2): 141-147_20151-7. pogdoi:10.1093/deafed/env058

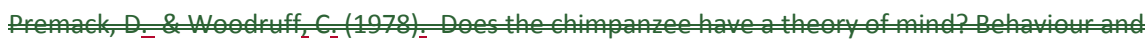
Buinscies, $4,515-526$

Peterson, C.C., C; O'Reilly, K. \& Wellman, H.M. (2016a). Deaf and hㅐearing Cechildren's

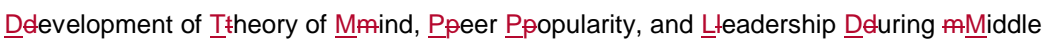
Cchildhood._See comment in PubMed Commons below Journal of Experimental Child PsycholJournal of Experimental Child Psychology 149:146-58. doi: 10.1016/j.jecp.2015.11.008

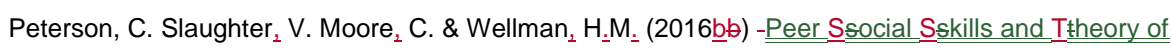

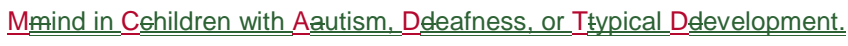

See comment in PubAted Commons belowDevelopmental Psychology. 2016 Jan;52(1):46-57. doi: 10.1037/a0039833. Epub 2015 Nov 2. Peer social skills and theory of mind in children with autism, deafness, or typical development. 


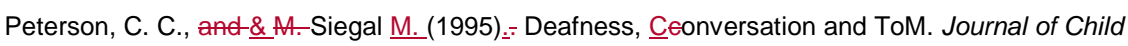
Psychology \& Psychiatry, 36, 459-474. doi:10.1111/i.1469-7610.1995.tb01303.xDOI

Peterson, C. C., \& Siegal, M. (1998). Changing Ffocus on the Rfepresentational mMind: Deaf,

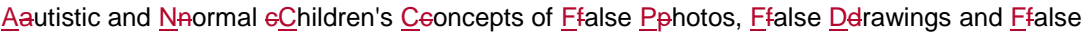
Bbeliefs. British Journal of Developmental Psychology, 16, 301-20. doi:10.1111/i.2044835X.1998.tb00754.X

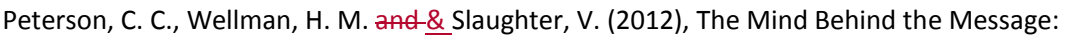
Advancing Theory-of-Mind Scales for Typically Developing Children, and Those With Deafness, Autism, or Asperger Syndrome. Child Development, 83:-469-485. doi:-10.1111/j.1467-

8624.2011.01728.x

Peterson $\mathrm{C}_{1}$. (2015). Empathy and Theory of Mind in Deaf and Hearing Children Doi: 10.1093/deafed/env058. JOURNAL??

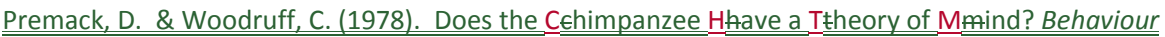
and Brain Sciences, 1 는 (4), 515-526. doi:10.1017/S0140525X00076512

Polettia, M., Enricic I., Bonuccellia B., Adenzatoc D. (2011) Theory of Mind in Parkinson's disease Behavioural Brain Research Volume 219, Issue 2, 1 June 2011, Pages 342-350

Ruffman, T., Slade, L., \& Crowe, E. (2002). The relation between children's and mothers' mental state tanguage and theory-of-mind understanding. Child Development, 73, 734-751. 
Russell, P. A., J. A. Hosie, C.D. Gray, C. Scott, N. Hunter and_\&___Banks, J., (1998). The Dedevelopment of ToM in $\underline{D}$ deaf $\underline{C}$ children. Journal of Child Psychology and Psychiatry, 39, 903-10. dDoi:10.1111/1469-7610.00390

Schick B., P. de Villiers, J. de Villiers andㅌ․ R.Hoffmeister R..(2007). Language and Theory of mind: A Study off Deaf Children. Child Development. -78 (2), -376-96. doi:-10.1111/j.1467-

\subsubsection{4.x}

Stansfield, J. \& Bunce, L.-, (2014). The Relationship Between Empathy and Reading Fiction: Separate Roles for Cognitive and Affective Components. Journal of European Psychology Students. 5(3); pp.9-18. ĐO1: http://doi.org/10.5334/jeps.cadoi:10.5334/jeps.ca

Stanzione ${ }_{L}$ C. \& Schick B.(2014). Environmental Ltanguage Ffactors in Ttheory of Mmind Delevelopment: Eevidence from $\underline{\text { CG }}$ hildren who are deaf/ heard of hearing or who have specific language impairment. Topics in Language Disorders._-734,. 296-312 doi:

\subsection{7/TLD.0000000000000038}

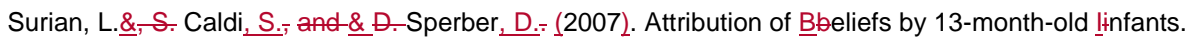
Psychological Science, 18(7): 580-586.

_doi:10.1371/journal.pone.0072835

Swanwick L R. \& Watson, L. (2007). Parents Sharing Books With Young Deaf Children in Spoken English and in BSL: The Common and Diverse Features of Different Language Settings-Settings. Journal of Deaf Studies and Deaf Education. 12-(3): 385-405. doi:-10.1093/deafed/enm004 
Swanwick ${ }_{L}$ R. \& Marschark ${ }_{L}$ M. (2010). Enhancing Education for Deaf

Children: Research into Practice and Back Again ${ }_{\cdot-5}$ Deafness \& Education International, 12 (4)

217-235. doi: 10.1179/1557069X10Y.0000000002

Swindells R. (1995) Stone Cold. Puffin Teenage Fiction

Symons, D. K., Fossum, K. \& Collins, T.B. K. (2006)_. A Longitudinal Study of Belief and Desire State Discourse During Mother-Child Play and Later False Belief Understanding. Social Development, 15:-676-692. doi:-10.1111/j.1467-9507.2006.00364.x

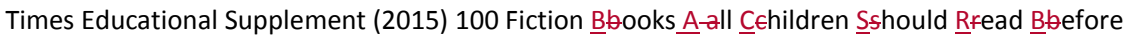
Lleaving p Primary s_school. www.tes.com/news/school-news/breaking-news/100-fiction-books-allchildren-should-read-leaving-primary-school-\%E2\%80\%93

The Guardian (2014) Diverse $\underline{V} \forall$ oices: the 50 B www.theguardian.com/childrens-books-site/2014/oct/13/50-best-culturally-diverse-childrens$\underline{\text { books }}$

Wellman, H. M. and \& Liu, D. (2004) $-\bar{j}$ Scaling of Theory-of-Mind Tasks. Child Development, 75:-523-541. doi:-10.1111/j.1467-8624.2004.00691.x 
Westby C. \& Robinson L. (2014). A Developmental Perspective for Promoting Theory of Mind._Topics in Languagee_ Disorders, 34 (4) 362-382 doi:-10.1097/TLD.0000000000000035

Wimmer, H., and \& J.Perner J.(1983). Beliefs about beliefs: Representation and constraining function of wrong beliefs in young children's understanding of deception. Cognition, 13, 103-128. Doi:10.1016/0010-0277(83)90004-5

Wood, D., Wood, H., Griffiths, A. \& Howarth, I. (1986) Teaching and Tұalking Wwith Deleaf Cehildren. John Wiley. ISBN 0471908274

Woolfe, T., \& Smith, P. K. (2001). The Sself-esteem Esteem and C $\in$ eohesion to Ffamily $\underline{\text { Mmembers of }}$

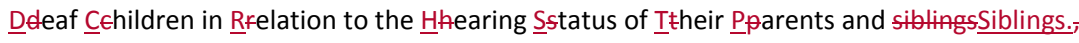
Deafness and Education International, 3, 80-96.

Woolfe, T., Want, S., \& Siegal, M. (2002). Signposts to $\underline{D}$ development: Theory of Mmind in Deaf Cehildren. Child Development, 73, 768-778. doi:10.1002/dei.100

Woolfe, T., Want, S., \& Siegal, M. (2003) Siblings, CEeonversation, and Ttheory of m $\underline{M}$ ind in $\underline{D}$ deaf ANative Ssigning CÉ hildren $_{\dot{-j}}$ Journal of Deaf Studies and Deaf Education, 340-347. $\underline{\text { doi:10.1093/deafed/eng023 }}$

Zunshine, L. (2011). Style Brings in Mental States. Style, 45(2):349-56. 
<smiles>C=C</smiles> 
Reviewer 1:

\begin{abstract}
This paper is important to understand how reading can facilitate ToM skills. Your research on this, in the context of deaf children, is highly needed and currently not commonly found in the literature. There are several recommendations to improve this manuscript:
\end{abstract}

(1) DEl style formatting - there is a mix of font sizes and font types; corrections of Latin word abbreviations, ie (should be i.e.), and et al (et al.), citations in the body text which has ampersand ' $\&$ ' outside the parentheses and the word 'and' within the parentheses, inconsistent number of space bars at the beginning of sentences, and various width of spacing between paragraphs, and a few more that I have indicated in the attached manuscript.

(2) In the method - how did the teachers 'choose' the fictions that the author analyzed - and what are pertinent information regarding the teachers whose fiction are included in the analysis - where they work, how many children with deafness they work with, how often do they use the book, how do they use the books, etc.

Another important point is regarding revision of some phrasings/sentences/paragraphs - this is compulsory to improve clarity and ease of reading please see manuscript

(3) Conclusion - it should have more information on the actual fiction content analysis - does the fiction analysis serve as a basis for others to select books with ToM contents? Future research possibilities in terms of analysing fiction ToM contents?

(4) Title - the inclusion of the phrase 'ToM understanding in deaf children' in the title made me assume that deaf children were actually the participants of this study, and that their understanding of ToM will be measured, analyzed and discussed - which was not the case. I suggest the author to reconsider the title, perhaps including the phrase "..... analyzing fiction with Theory of Mind concepts used by Teacher-of-the-Deaf"

(5) The reference list needs a major rework to adhere to the DEI format - e.g., on the top of the list, a hidden line would reappear when Word doc paragraph formatting is switched on, one reference is cited twice, and the entire list is inconsistently styled and formatted. Please see my comments on the manuscript.
Many thanks for your comments. I agree that there is a paucity of research in this area and hope that DEI will provide the opportunity to enhance this discussion.
Many thanks for your patience. I appreciate the difficulty this causes in reading the submission. I have corrected errors and double checked for consistency.
This is a follow-on from two other papers, one which was printed in DEI and another which is currently in press with a different journal. I have included a brief summary of pertinent information regarding the teachers.

I have corrected errors in order to support the reader's ease of engaging with the text. Many thanks for your comments in the manuscript

Many thanks for your comment. I have been able to expand the conclusion and cover the points you raise. I have specifically discussed future research possibilities.

Many thanks for your comment. I have reconsidered the title. I do see how the original title might be misleading.

I would welcome your comments on the new title.
Many thanks for your patience. The reference list has been significantly overhauled 


\section{Reviewer \#2}

The topic of the development of Theory of Mind in deaf children is both interesting and relevant for the readership of the journal. The use of picture books with deaf children to encourage language development, and the encouragement given to parents of deaf children to move their discussion beyond the text has long been established. This paper seeks to link this to the development of ToM by analysing the opportunities to discuss states of mind and understanding that might lead to the development of ToM that arise from some specific picture books.

The introduction contains a detailed review of the literature around the development of ToM. The author/s reference a great deal of supporting literature, which could be reduced somewhat since at present it can interfere with the reading of the manuscript.

As stylistic issues, the author/s are inconsistent in the use of 'and' or ' $\&$ ' in the manuscript and reference list. The convention is to use 'and' when two names are quoted in the text (Woolfe and Smith, 2001) and to use ' $\&$ ' in the reference list. In addition, the author/s use speech marks (") rather than quotation marks (') throughout the text and this should be amended and the use of 'intra' and 'inter' needs to be checked.

The author/s then present two questions relating to the use of books to promote ToM development. Under 'Methodology' the author/s make it clear that this paper emerges from a study that has been reported elsewhere. In this paper, no explanation is given as to the criteria for the selection of the books, or whether the five books considered here represented a selection of the books used. Further explanation is required. The adapted schedule that is included as Appendix 1 would be better included as a Table in the text so that it is readily available to the reader.

In the results, there is a detailed consideration of the aspects of each of the five books selected that could possibly be used to exploit the development of ToM in deaf children, with the suggestion that there is a need to look beyond the surface elements of a book
Many thanks for your comments. As you comment, I do think the topic is relevant for the readership . As I receive lots of contact from Uk ToDs asking for information that the paper answered I am pleased to see how you have acknowledged this.

Many thanks for your comment. I have reduced some of the references (where I have sufficient evidence from other sources already listed) and hope this supports readability. As you will appreciate, being very close to the work can bring its challenges in knowing what to leave out but as you suggest there is a fine line between providing evidence and "information overload".

Many thanks for your patience with this matter. I have corrected the use of 'and' and ' $\&$ ' throughout the document and the reference list. I have also undertaken a thorough check for speech marks and replaced these with quotation marks.

The use of "intra" and "inter" is now correct and consistent with the usage in Westby \& Robinson (2014) I did have an error in one place - many thanks for picking this up.

Many thanks for your comment. I can see what you are referring to in terms of the methodology and agree this is not clear for the reader as to how the books were selected. I have sought to explain this further in the paper within the methodology

The impetus is really to show people who work with deaf children that ToM is present (to varying degrees and with varying aspects of) in children's literature and the opportunities we may have to draw on this.

I have changed Appendix 1 so that it is now a table within the text and agree this is more readily available to the reader. The numbering of the other appendices has therefore also changed

Many thanks for your positive comment regarding the intention of the paper and the need to deeply investigate booksharing from a ToM point of view. 
(number of pages; number of words per page, etc) to uncover opportunities for discussion around aspects of ToM that a book may present. This is highly relevant information. However, in order to address the second question posed at the start of the paper, the author/s need to research how adults exploit the aspects of the stories that have been highlighted (or maybe this has been reported elsewhere) and whether explicit intervention on how to develop ToM using the framework discussed proves beneficial. Without this further information, the paper simply presents an analysis of five story books to uncover aspects of the story that could be used to encourage the development of ToM.
The ways that ToDs exploit ToM within a booksharing activity is in the process of being reported elsewhere. I have sought to explain this in the text and referenced to the other paper. If the other paper is published first then this may be added into the DEI paper. I have sought to make it clearer in the text as to the importance of understanding ToM developmentally so that ToDs are able to exploit the books for these higher level skills which have been demonstrated to be more challenging, even for deaf children of deaf parents where the assumption throughout has been that development will be typical.

\section{Notes to both reviewers}

Many thanks for identifying the potential and need for this paper. I receive regular emails from professionals who form part of your readership about this topic and believe that this paper will help me to signpost them to relevant information which will then be accessible within the professional domain. Many thanks for your patience with the style and formatting errors in the text. I am extremely pleased with the feedback provided which has helped me to significantly improve the paper for the readership. Thank you for responding to the first submission in such a timely fashion which has made submitting to DEI a very positive experience. I hope the paper has moved forward significantly in order to move towards publication. 


\begin{tabular}{|c|c|c|c|c|c|c|c|}
\hline Book & $\begin{array}{l}\text { Number } \\
\text { of Pages }\end{array}$ & Linguistic features & Illustrative content & $\begin{array}{l}\text { Mean } \\
\text { Words per } \\
\text { page }\end{array}$ & $\begin{array}{l}\text { Mental state } \\
\text { terms }\end{array}$ & $\begin{array}{l}\text { Emotional state } \\
\text { terms }\end{array}$ & Characters \\
\hline $\begin{array}{l}\text { The } \\
\text { Gruffalo }\end{array}$ & 22 & $\begin{array}{l}\text { End rhyme } \\
\text { Repetition } \\
\text { Imagery e.g. Gruffalo crumble, } \\
\text { scrambled snake }\end{array}$ & $\begin{array}{l}\text { Detailed cartoon style } \\
\text { Closely follows } \\
\text { narrative }\end{array}$ & 29 & Know & Afraid & $\begin{array}{l}\text { Animals } \\
\text { Fictional creature (The } \\
\text { Gruffalo) }\end{array}$ \\
\hline $\begin{array}{l}\text { Handa's } \\
\text { Surprise }\end{array}$ & 24 & $\begin{array}{l}\text { Repetition } \\
\text { Some vocabulary uncommon to UK } \\
\text { children e.g. guava }\end{array}$ & $\begin{array}{l}\text { Detailed cartoon style } \\
\text { Depicts Kenyan } \\
\text { culture } \\
\text { Closely follows } \\
\text { narrative }\end{array}$ & 4 & Wonder, surprise & None & $\begin{array}{l}\text { Human, true to life } \\
\text { Animals }\end{array}$ \\
\hline $\begin{array}{l}\text { Arthur's } \\
\text { Tractor }\end{array}$ & 24 & $\begin{array}{l}\text { Ideophones (chugga thrum, thud, } \\
\text { eeek) } \\
\text { Figurative language } \\
\text { Some invented / unfamiliar } \\
\text { technical language e.g. sprocket } \\
\text { spring sprigget }\end{array}$ & $\begin{array}{l}\text { Detailed cartoon style } \\
\text { showing background } \\
\text { and foreground } \\
\text { Illustrations show } \\
\text { more than narrative }\end{array}$ & 20 & None & None & $\begin{array}{l}\text { Human, true to life (Arthur) } \\
\text { Fictional (dragon) } \\
\text { Fairytale (princess, knight) }\end{array}$ \\
\hline $\begin{array}{l}\text { Eat Your } \\
\text { Peas }\end{array}$ & 24 & $\begin{array}{l}\text { Repetition } \\
\text { Simple common words }\end{array}$ & $\begin{array}{l}\text { Closely follows } \\
\text { narrative } \\
\text { 2D cartoon style } \\
\text { Bold colours } \\
\text { Close up images of } \\
\text { characters' } \\
\text { expressions }\end{array}$ & 21 & None & Knew, want & Human, true to life \\
\hline $\begin{array}{l}\text { Mrs } \\
\text { Rainbow }\end{array}$ & 32 & $\begin{array}{l}\text { Some complex words } \\
\text { (unanimously, reluctantly, emerge) }\end{array}$ & $\begin{array}{l}\text { Bright and bold } \\
\text { colours } \\
\text { 2D cartoon style } \\
\text { Closely follows } \\
\text { narrative }\end{array}$ & 38 & Believe, think & $\begin{array}{l}\text { Happy, worried, } \\
\text { excites, glad, sad, } \\
\text { courage, } \\
\text { embarrassment }\end{array}$ & Human, true to life \\
\hline
\end{tabular}

